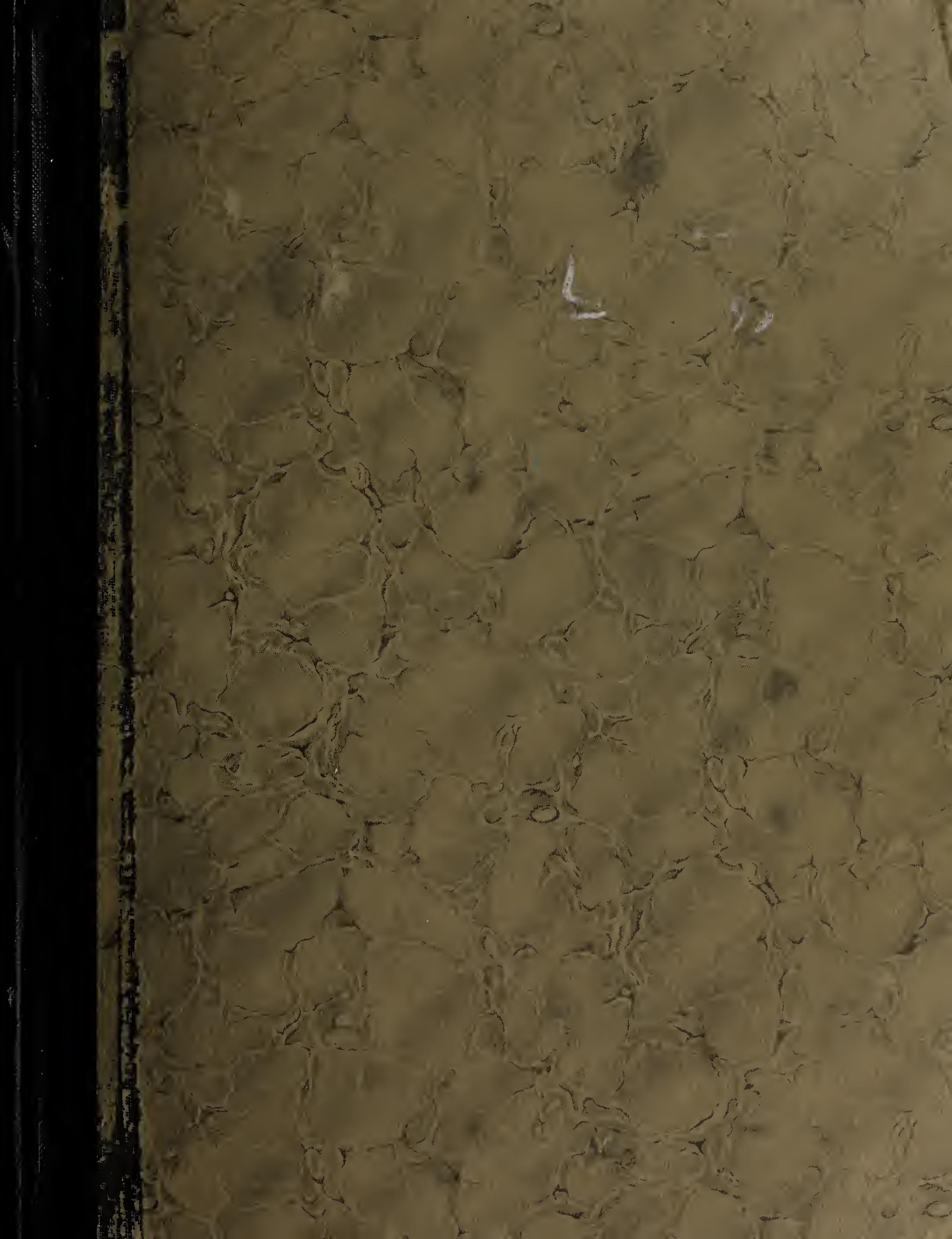


Digitized by the Internet Archive in 2019 with funding from Brigham Young University 
Please do not destroy or throw away this publication. If you have no further use for it, write to the Geological Survey at Washington and ask for a frank to return it

\author{
DEPARTMENT OF THE INTERIOR \\ HUBERT WORK, Secretary \\ United States Geological SURVey \\ George OTIS Sмith, Director
}

Professional Paper 132-A

\title{
ROCK FORMATIONS IN THE COLORADO PLATEAU OF SOUTHEASTERN UTAH AND NORTHERN ARIZONA
}

BY

C. R. LONGWELL, H. D. MISER, R. C. MOORE, KIRK BRYAN, AND SIDNEY PAIGE

Published July 27, 1923

Shorter contributions to general geology, 1923

(Pages 1-23)

-

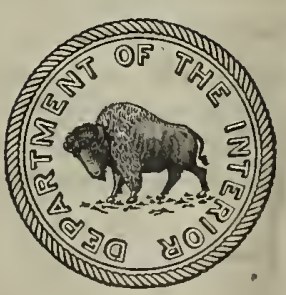

WASHINGTON

GOVERNMENT PRINTING OFFICE

1923 


\section{CONTENTS.}

Nature and purpose of investigation..............

Previous work..........................

Topography.................................

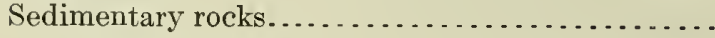

General features........................

Carboniferous system ....................

Goodridge formation.................

Supai (?) formation...................

Coconino sandstone..................

Kaibab limestone......................

Erosion interval........................

Triassic system........................

Moenkopi formation.....................

Shinarump conglomerate................

Chinle formation.

Jurassic system..........................

General features. . . . . . . . . . . . . . . . . . .

Wingate sandstone.

\begin{tabular}{r|} 
Page. \\
1 \\
1 \\
2 \\
2 \\
2 \\
7 \\
7 \\
7 \\
8 \\
8 \\
9 \\
9 \\
9 \\
10 \\
11 \\
11 \\
11 \\
12
\end{tabular}

Sedimentary rocks-Continued.

Jurassic system-Continued.

Todilto (?) formation

Navajo sandstone.

Gypsiferous shales and sandstones....

Varicolored sandstones and shales.......

McElmo formation (Cretaceous?)..............

Cretaceous system.

Dakota (?) sandstone.

"Tununk shale".

Tununk sandstone.

"Blue Gate shale'.......................

Blue Gate sandstone..................

"Masuk shale".

Masuk sandstone......................

Tertiary system ..............

Local sections..........................
Page.

\section{ILLUSTRATIONS.}

Plate I. Generalized columnar sections of the Paleozoic and Mesozoic rocks of northern Arizona and southeastern Utah.

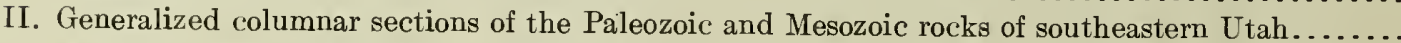

III. A, View looking down San Juan Canyon, Utah, at a point 9 miles by stream above Honaker trail; $B$, View looking down Green River toward its junction with Colorado River, Utah; $C$, View in Cataract Canyon of the Colorado, Utah.

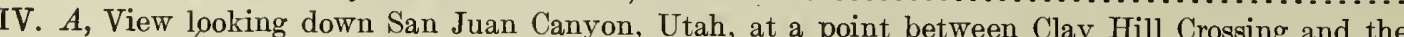
mouth of Moonlight Creek; $B$, View near Colorado River 2 miles below mouth of Trachyte Creek, Utah; , View looking down San Juan Canyon at the mouth of Slickhorn Gulch, Utah

V. $A$, View looking southwest down head of Marble Canyon from point near Lees Ferry, Ariz.; $B$, View looking up Colorado River from a high point near the mouth of Crescent Creek, Utah; $C$, Erosion remnants standing on platform of Coconino sandstone near mouth of Fremont River, Utah

VI. $A$, View looking up San Juan Canyon from point near mouth of Clay Gulch, Utah; $B$, View looking west toward high mesa at Clay Hill Crossing on San Juan River, Utah...............

VII. $A$, Castle Butte, near mouth of Red Canyon, Utah; $B$, View looking north across Colorado River at Lees Ferry, Ariz.

VIII. $A$, View looking northwest up Colorado River toward proposed dam site near Lees Ferry, Ariz.; $B$, View from point half a mile south of Spencer Camp looking south down San Juan Canyon toward Navajo Mountain, Utah...

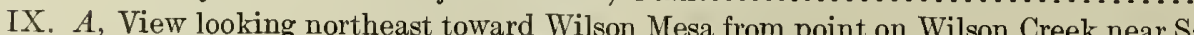
Utah; $B$, View looking across Colorado River opposite Smith's Fork, Utah; $C$, Sheer cliff of Navajo sandstone at Warm Spring Creek on Colorado River, Utah.

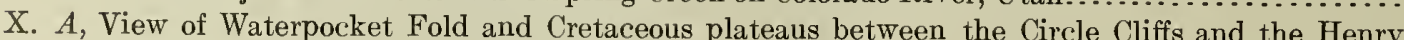
Mountains, Utah; $B$, Sketch of the country between the Circle Cliffs and the Henry Moun-

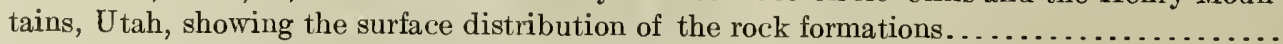

Figure 1. Index map of parts of Utah and Arizona showing location of columnar sections given in Plates I and II 


\title{
SHORTER CONTRIBUTIONS TO GENERAL GEOLOGY, 1923.
}

\author{
ROCK FORMATIONS IN THE COLORADO PLATEAU OF SOUTHEASTERN \\ UTAH AND NORTHERN ARIZONA.
}

\author{
By C. R. Longwell, H. D. Miser, R. C. Moore, Kirk Bryan, and Sidney Paige.
}

NATURE AND PURPOSE OF THE INVESTIGATION.

The field work of which this report is a record was done in the summer and fall of 1921 by members of the United States Geological Survey. A project to build a large storage dam at Lees Ferry, on Colorado River in northern Arizona, called for a detailed topographic survey of the area covered by the project, for the purpose of determining the capacity of the reservoir. This work was undertaken by the United States Geological Survey in cooperation with the Southern California Edison Co. Three surveying parties were sent to the field, each accompanied by a geologist, whose specific duty was to study and report on the rock formations within the area to be flooded.

One topographic party, under A. T. Fowler, which started at Lees Ferry and worked upstream in Arizona, was accompanied by Kirk Bryan. Another party, under K. W. Trimble, which started near Bluff and worked down the San Juan and thence down the Colorado, was accompanied by H.D. Miser. The third party, under W. R. Chenoweth, worked from Fremont River to the Waterpocket Fold and then returned to Green River, Utah, and traversed Cataract Canyon during the period of low water. C. R. Longwell was with this party until September, when his place was taken by Sidney Paige. Mr. Paige, in company with the Kolb brothers, E. C. La Rue, and Henry Rauch, left the Chenoweth party after Cataract Canyon had been surveyed and rowed down the Colorado to the mouth of the San Juan, where they were joined by Mr. Miser. Then they took a hurried trip by boat down the Colorado to Lees Ferry, making a few short stops and visiting the famous Rainbow Bridge.
Thus the geology of the canyons of Colorado and San Juan rivers and of the lower parts of tributary canyons was examined continuously, and reconnaissance work was done in the country back from the rivers. At the same time a fourth party, under R. C. Moore, was mapping parts of Kane, Garfield, and Wayne counties, Utah, to determine whether oil might be found there.

The present paper includes brief descriptions of the rocks of the regions traversed, detailed geologic sections, and columnar sections measured not only by the geologists who accompanied these parties but by other geologists who have worked in the same regions or in adjoining regions. The positions of the columnar sections measured and many of the other sections are shown on Figure 1.

\section{PREVIOUS WORK.}

The first geologic work done in the area here considered was that recorded in the report of the Macomb expedition of 1859 by J. S. Newberry, ${ }^{1}$ who examined the Mesozoic formations near Bluff. Next followed J. W. Powell's historic explorations in 1869 to 1872 , which contributed some geologic information, although their most valuable results were geographic. ${ }^{2}$ G. K. Gilbert's work in 1875 and 1876 was necessarily of a reconnaissance nature, but it showed powers of observation and interpretation that have aroused the admiration of later workers who have used his report ${ }^{3}$ as a guide.

1 Newberry, J. S., Geological report, in Report of the exploring expedition from Santa Fe, N. Mex., to the junction of the Grand and Green rivers of the Great Colorado of the West, in 1859, under the command of Capt. J. N. Macomb, pp. 101-109, 1876.

${ }^{2}$ Powell, J. W., Exploration of the Colorado River of the West, 1875. 3 Gilbert, G. K., Report on the geology of the Henry Mountains, U.S. Geog. and Geol. Survey Rocky Mitn. Region, 1880. 
W. H. Holmes contributed information on the San Juan district, ${ }^{4}$ in a report on field work that was in part contemporaneous with that done by Gilbert farther north and west. The classic reports of Gilbert and Holmes served all practical needs for a knowledge of this sparsely settled region until oil was discovered at Goodridge in 1908. H. E. Gregory ${ }^{5}$ and E. G. Woodruff ${ }^{6}$ made reports on the geology of the oil field, and Gregory later, in his reports on the Navajo country, ${ }^{7}$ described the geology of the region on the south side of the San Juan. The most recent papers of direct interest in the present connection are those by W. B. Emery ${ }^{8}$ C. L. Dake, ${ }^{9}$ Dorsey Hager, ${ }^{10}$ C. T. Lupton, ${ }^{11}$ and R. C. Moore. ${ }^{12}$ Numerous papers on adjacent areas, herein referred to, have been of great assistance in making correlations.

\section{TOPOGRAPHY.}

The area considered in this report is part of a large arid region that is sparsely settled and difficult of access. It is a typical portion of the Colorado Plateau, characterized by canyons, cliffs, mesas, and buttes. The general plateau surface, averaging between 5,000 and 6,000 feet in altitude, appears fairly regular and continuous in a panoramic view; but Colorado River and its tributaries have cut hundreds of feet below the general level, and Navajo Mountain and the Henry Mountains project conspicuously above it, attaining maximum altitudes of about 11,000 feet. The Henry Mountains are classic as the type locality of the igneous intrusive masses known as laccoliths. Northwest of these mountains are the so-called High Plateaus, lofty forest-clad tablelands with gently irregular surface topography

1 Holmes, W. H., Geological report on the San Juan district: U. S. Geog. and Geol. Survey Terr. Ninth Ann. Rept., for 1875, pp. 237-276, 1877.

${ }^{5}$ Gregory, H. E., The San Juan oil field, Utah: U. S. Geol. Survey Bull. 431, pp. 11-25, 1911.

6 Woodruff, E. G., Geology of the San Juan oil field, Utah: U. S. Geol. Survey Bull. 471, pp. 76-104, 1912.

7 Gregory, H. E., The Navajo country: U. S. Geol. Survey WaterSupply Paper 380, 1916; Geology of the Navajo country: U. S. Geol. Survey Prof. Paper 93, 1917.

8 Emery, W. B., The Green River Desert section, Utah: Am. Jour. Sci., 4 th ser., vol. 46, pp. 551-577, 1918.

- Dake, C. L., The pre-Moenkopi unconformity of the Colorado Plateau: Jour. Geology, vol. 27, pp. 61-74, 1920: Horizon of the marine Jurassic of Utah: Jour. Geology, vol. 27, pp. 634-646, 1919.

${ }_{10}$ Hager, Dorsey, Oil possibilities of the Holbrook area in northeast Arizona, 1921. A private publication.

il Lupton, C. T., Geology and coal resources of Castle Valley, Utah: U. S. Geol. Survey Bull. 628, 1916.

12 Moore, R. C., On the stratigraphy of northeastern Arizona: Am. Assoc. Petroleum Geologists Bull., vol. 6, No. 1, pp. 47-49, 1922. Discusses paper by Hager cited above. and precipitous borders, which have an average altitude of more than 9,000 feet.

Alternating sedimentary formations of varying resistance exert a strong topographic control. Heavy sandstone and limestone units form vertical cliffs or level mesa tops; shales produce slopes or local areas of badlands. Stream courses cut into sandstone or limestone are confined in narrow, steep-walled canyons; but at horizons of thick shales the valleys are wide, with vertical outer walls made by the overlying sandstones. Typical cross sections of the larger streams show prominent structural terraces or benches, which mark abrupt changes in the character of the rocks.

\section{SEDIMENTARY ROCKS. GENERAL FEATURES.}

The nakedness of the surface rocks and their deep dissection give an excellent opportunity for detailed study, and when the entire region has been systematically surveyed there should be few important problems of correlation left unsolved. But in spite of the apparent simplicity of the geology it is not safe to attempt correlation of widely separated sections without knowledge of the intervening areas, however thorough the study of the sections may have been. Errors have already resulted from such attempts, and a certain degree of confusion now exists as to the exact stratigraphic succession and the proper terminology. Many of the formations are of continental origin, and some have yielded no determinable fossils. Certain of these formations have lithologic characteristics that are remarkably persistent over wide areas; but in many sections two or more formations are strikingly similar in general appearance, and members that are of only local distribution may be confused with formations that are considered the most trustworthy as guides to correlation. In correlating these deceptive formations, therefore, it is desirable to measure sections as close together as possible, and continuous tracing in the field is the most satisfactory method. The rocks are essentially horizontal or dip gently, except for local strong flexures, and the present writers found it possible to follow certain guide horizons essentially without interruption.

The rocks range in age from Pennsylvanian to Tertiary, but the Tertiary formations were not studied in detail. Triassic and Jurassic rocks are the most widely distributed forma- 
tions on the surface, and they are largely of continental origin. Bright colors prevail, making the region a "painted desert" of great scenic interest. In Utah the older formations are revealed in a few broad anticlines, notably in Cataract Canyon and in the San Juan oil field; and in the adjoining part of Arizona they appear in Marble Canyon.

Besides the laccoliths of igneous rocks in the Henry Mountains there are a few igneous dikes and volcanic necks at other places in the part of the Colorado Plateau under discussion. In the High Plateaus, west of the Henry Mountains, there are large areas of extrusive igneous rocks. None of these igneous rocks are here described.

The section exposed in the walls of the Grand Canyon, which adjoins Marble Canyon, is probably better known than any other in the Colorado Plateau, and it is taken as a standard in correlating Paleozoic formations in the region. This section has been studied in great detail by L. F. Noble, and he has recently proposed some changes in the stratigraphic subdivision and the terminology to be used. ${ }^{13}$ (See Fig. 1 and Pl. I.)

${ }^{13}$ Noble, L. F., in Schuchert, Charles, On the Carboniferous of the Grand Canyon of Arizona: Am. Jour. Sci., 4th ser., vol. 45, pp. 347-362, 1918. Noble, L. F., Paleozoic formations of the Grand Canyon at the Bass trail: U. S. Geol. Survey Prof. Paper 131, pp. 23-73, 1922.
His usage is indicated below, in comparison with the older usage, with a view to making clearer the discussion of Paleozoic formations here presented.

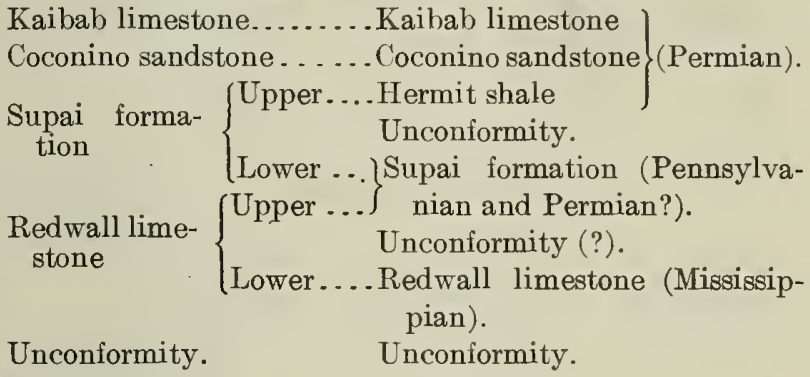
tions.

In thus redefining the Supai and Redwall formations Noble has definitely referred the Hermit shale to the Permian on the basis of plant remains first discovered by Schuchert and identified by David White. No fossils have been found in the thick red sandstone at the top of the Supai formation as redefined, and this member may therefore belong either in the Permian or in the Pennsylvanian.

The rock formations studied in southeastern Utah and the adjoining part of Arizona are indicated in the following table:

Rock formations in southeastern Utah and the adjoining part of Arizona.

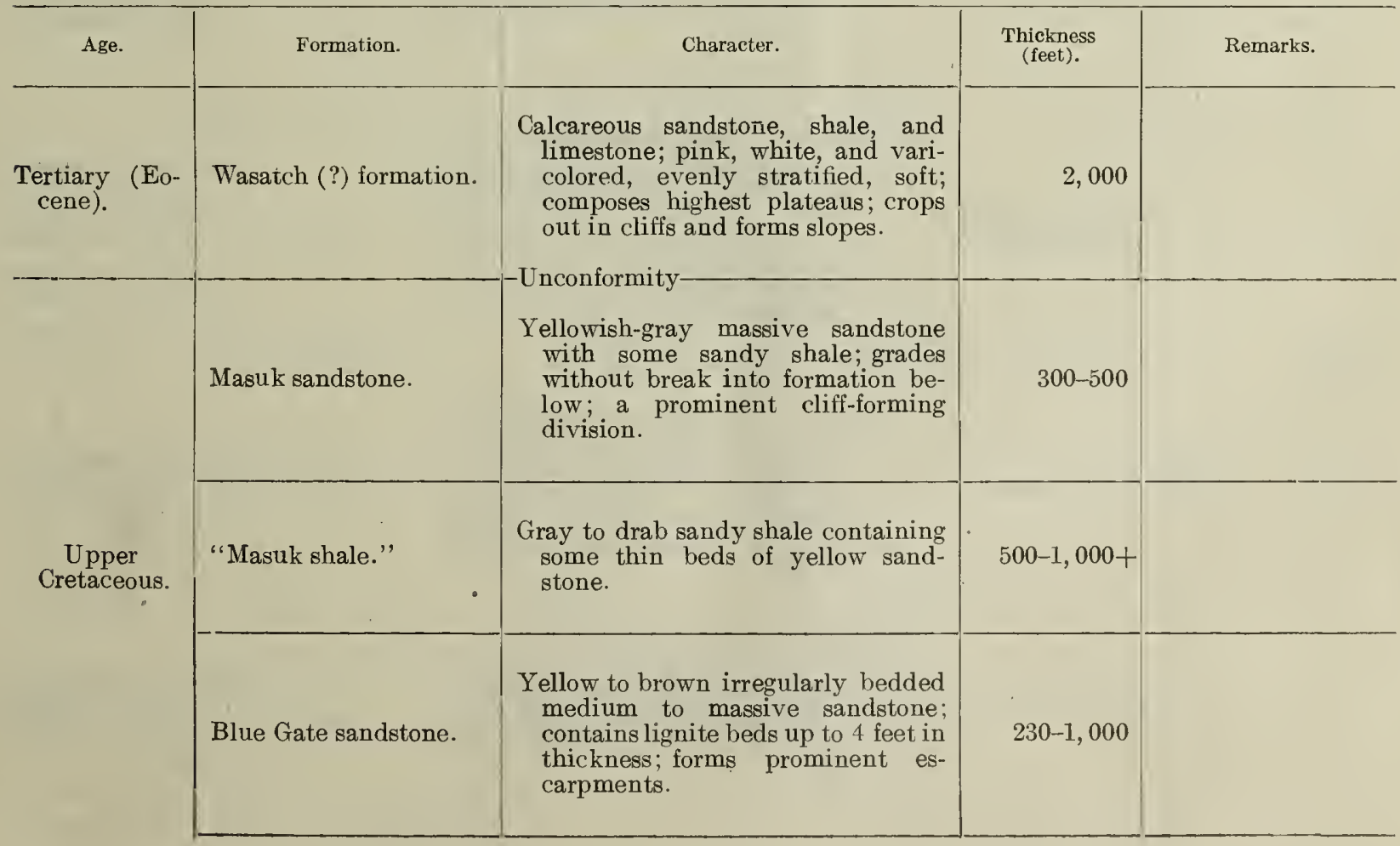


Rock formations in southeastern Utah and the adjoining part of Arizona-Continued.

\begin{tabular}{|c|c|c|c|c|}
\hline Agə. & Formation. & Character. & $\begin{array}{l}\text { Thickness } \\
\text { (feet). }\end{array}$ & Remarks. \\
\hline \multirow{4}{*}{$\begin{array}{l}\text { Upper } \\
\text { Cretaceous. }\end{array}$} & "Blue Gate shale." & $\begin{array}{l}\text { Bluish-drab argillaceous to sandy } \\
\text { shale; very uniform in color and } \\
\text { texture; forms slopes and badlands; } \\
\text { thickness, } 1,100-1,200 \text { feet. }\end{array}$ & \multirow{3}{*}{$2,115-2,250$} & \\
\hline & Tununk sandstone. & $\begin{array}{l}\text { Yellowish medium to massive irreg- } \\
\text { ularly bedded sandstone; contains } \\
\text { lignite; forms escarpments and } \\
\text { hogbacks; thickness, } 60-100 \text { feet. }\end{array}$ & & \\
\hline & "Tununk shale." & $\begin{array}{l}\text { Bluish-drab sandy shale grading to } \\
\text { fossiliferous sandstone at base; } \\
\text { shale contains abundant Gryphaea } \\
\text { newberryi and other fossils; thick- } \\
\text { ness, } 900-1,000 \text { feet. }\end{array}$ & & \\
\hline & Dakota (?) sandstone. & $\begin{array}{l}\text { Yellow to nearly white sandstone; } \\
\text { conglomeratic in part; irregularly } \\
\text { bedded; contains lignite locally. }\end{array}$ & $0-100$ & \\
\hline \multirow[t]{3}{*}{$\begin{array}{l}\text { Cretaceous (?) } \\
\text { (Lower Cre- } \\
\text { taceous ?). }\end{array}$} & McElmo formation. & $\begin{array}{l}\text { Maroon to light bluish-gray sandy } \\
\text { banded shale; conglomerate; and } \\
\text { coarse gritty maroon, yellow, and } \\
\text { gray irregularly bedded sandstone; } \\
\text { forms escarpments. }\end{array}$ & $125-565$ & \\
\hline & $\begin{array}{l}\text { Varicolored sandstones } \\
\text { and shales. }\end{array}$ & $\begin{array}{l}\text { Very massive soft light creamy- } \\
\text { white, tan, and orange-brown cross- } \\
\text { bedded sandstone; grades into very } \\
\text { sandy shale; weathers readily in } \\
\text { rounded slopes and forms abundant } \\
\text { dune sand. }\end{array}$ & $170-1,430$ & $\begin{array}{l}\text { Navajo sandstone of } \\
\text { Emery. Included } \\
\text { by Lupton in Mc- } \\
\text { Elmo formation. }\end{array}$ \\
\hline & $\begin{array}{l}\text { Gypsiferous shales and } \\
\text { sandstones. }\end{array}$ & $\begin{array}{l}\text { Pink to red and bluish sandy shale, } \\
\text { gypsum in beds up to } 5 \text { feet thick, } \\
\text { and massive white sandstone; } \\
\text { forms badlands; } 50-300 \text { feet. } \\
\text { Shale, sandstone, and siliceous } \\
\text { dark-maroon and light bluish-green } \\
\text { limestone; forms distinct escarp- } \\
\text { ment; } 30-55 \text { feet: }\end{array}$ & $45-450$ & $\begin{array}{l}\text { Todilto (?) formation } \\
\text { of Emery. Hori- } \\
\text { zon of marine Ju- } \\
\text { rassic. Included } \\
\text { in McElmo forma- } \\
\text { tion by Lupton. }\end{array}$ \\
\hline \multirow{2}{*}{ Jurassic. } & Navajo sandstone. & $\begin{array}{l}\text { Light creamy-yellow, white, pinkish, } \\
\text { and buff, highly cross-bedded, } \\
\text { very massive calcareous sandstone; } \\
\text { weathers in high cliffs and innu- } \\
\text { merable cones, towers, and domes; } \\
\text { forms caves, alcoves, and natural } \\
\text { bridges. }\end{array}$ & $500-1,800$ & $\begin{array}{l}\text { Grcgory's usage. In- } \\
\text { cluded in Wingate } \\
\text { sandstone by Em- } \\
\text { ery. }\end{array}$ \\
\hline & Todilto (?) formation. & $\begin{array}{l}\text { Maroon coarse-grained cross-bedded } \\
\text { sandstone; conglomerate; blue-gray } \\
\text { hard dense limestone; maroon and } \\
\text { brown shale. All in thin irregular } \\
\text { beds. }\end{array}$ & $125-249$ & $\begin{array}{l}\text { Gregory's usage. In- } \\
\text { cluded in Wingate } \\
\text { sandstone by Em- } \\
\text { ery. }\end{array}$ \\
\hline
\end{tabular}


ROCK FORMATIONS IN THE COLORADO PLATEAU OF UTAH AND ARIZONA.

Rock formations in southeastern Utah and the adjoining part of Arizona-Continued.

\begin{tabular}{|c|c|c|c|c|}
\hline Age. & Formation. & Character. & $\begin{array}{l}\text { Thickness } \\
\text { (feet). }\end{array}$ & Remarks. \\
\hline Jurassic. & Wingate sandstone. & $\begin{array}{l}\text { Reddish-brown very massive sand- } \\
\text { stone; prominently jointed; out- } \\
\text { cropping commonly in a single ver- } \\
\text { tical cliff resembling a palisade. } \\
\text { Cross-bedded but not so promi- } \\
\text { nently as Navajo sandstone. }\end{array}$ & $250-500$ & $\begin{array}{l}\text { Gregory's usage. In- } \\
\text { cluded in Wingate } \\
\text { sandstone by Em- } \\
\text { ery. }\end{array}$ \\
\hline Upper Triassic. & Chinle formation. & $\begin{array}{l}\text { Thick variegated calcareous shales or } \\
\text { "marls," fine-grained sandstones, } \\
\text { cherty limestones, and conglom- } \\
\text { eratic limestone. Sandstone most } \\
\text { abundant near top of formation. }\end{array}$ & $300-1,000$ & \\
\hline $\begin{array}{l}\text { Upper (?) Tri- } \\
\text { assic. }\end{array}$ & $\begin{array}{l}\text { Shinarump conglomer- } \\
\text { ate. }\end{array}$ & $\begin{array}{l}\text { Light-gray to yellow coarse-grained } \\
\text { to conglomeratic sandstone, very } \\
\text { irregularly bedded and variable in } \\
\text { thickness; grades locally into blu- } \\
\text { ish sandy shale; contains silicified } \\
\text { wood; forms prominent bench in } \\
\text { topography. }\end{array}$ & $0-220$ & \\
\hline Lower Triassic. & Moenkopi formation. & $\begin{array}{l}\text { Chocolate-brown to yellowish shale } \\
\text { and sandstone, containing locally } \\
\text { in upper portion very thin hard } \\
\text { limestones. The shale very sandy } \\
\text { and grading into shaly sandstones; } \\
\text { the sandstone ranging from thin- } \\
\text { bedded platy to thick massive } \\
\text { beds. Ripple-marked. Contains } \\
\text { DeChelly (?) sandstone lentil in } \\
\text { middle portion; thickness, 0-200 } \\
\text { feet. }\end{array}$ & $304-920$ & $\begin{array}{l}\text { Directly overlies } \\
\text { Coconino sand- } \\
\text { stone where Kai- } \\
\text { bab limestone is } \\
\text { absent. }\end{array}$ \\
\hline \multirow{3}{*}{ Permian. } & Kaibab limestone. & $\begin{array}{l}\text { White to yellowish massive more or } \\
\text { less dolomitic limestone; in part } \\
\text { cherty; lower part increasingly } \\
\text { sandy and grading into subjacent } \\
\text { sandstone without sharp change. } \\
\text { Fossiliferous in part. }\end{array}$ & $0-250$ & Not continuous. \\
\hline & Coconino sandstone. & $\begin{array}{l}\text { White to tan massive calcareous sac- } \\
\text { charoidal hard to friable sandstone. } \\
\text { In Circle Cliffs not differentiated } \\
\text { from Supai (?) formation. }\end{array}$ & $300-1,000$ & \\
\hline & Supai (?) formation. & $\begin{array}{l}\text { Red to light-yellow shale and sand- } \\
\text { stone. }\end{array}$ & 380 & $\begin{array}{l}\text { Possibly } \\
\text { shale. }\end{array}$ \\
\hline Pennsylvanian. & Goodridge formation. & $\begin{array}{l}\text { Bluish fine-grained dense, medium to } \\
\text { massively bedded limestone; red } \\
\text { and grayish-white sandstone, in } \\
\text { part petroliferous; red and dark- } \\
\text { gray sandy shales. Limestone pre- } \\
\text { dominates in lower part of section, } \\
\text { sandstone and shale in upper part. }\end{array}$ & 1,582 & \\
\hline
\end{tabular}




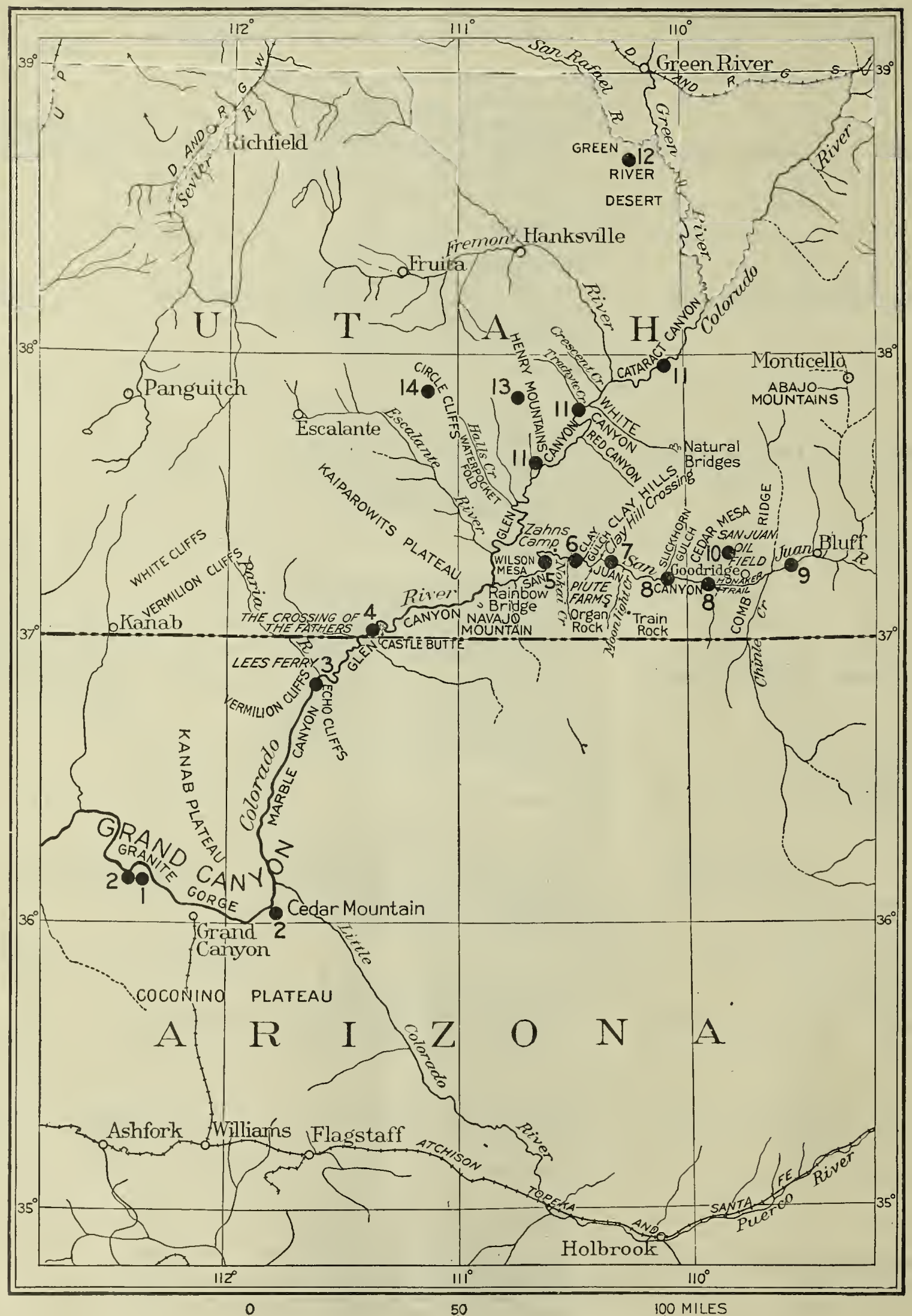

FIGURE 1.-Index map of parts of Utah and Arizona showing location of columnar sections (numbered dots) given in Plates I and II. Nos. 1 to 10 are given in Plate I; Nos. 11 to 14 in Plate II. 
2

Composite section at
Bass Trail and on
Cedar Mlountain in the Grond Canyon region
By L. F Noble. By L. F. Nobble,
Ut. S G Gol survey
Profosional Paper 1922

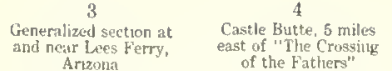 Arizona
By Kirk Bryan

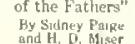
Wilson Mesa By H. D Mliser
Composite seetron
between Clay Gulch
and Zahns CCampo and Zahns Camp By H D Maser
7

(lay Hill crassing, Paute Farms Monnlizht CCreek
By H D Miser

\section{Composite section
at mouth of
Shch horn Gulch and Shlchhorn Gulch and
Honaker trail Honaker trail
By H D Maser}

$$
10
$$

Getheraluzed sectrin showing strata in

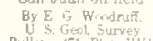

Genetalysd sestict San Juan River Mouth of Chinlec Creek

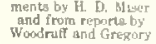

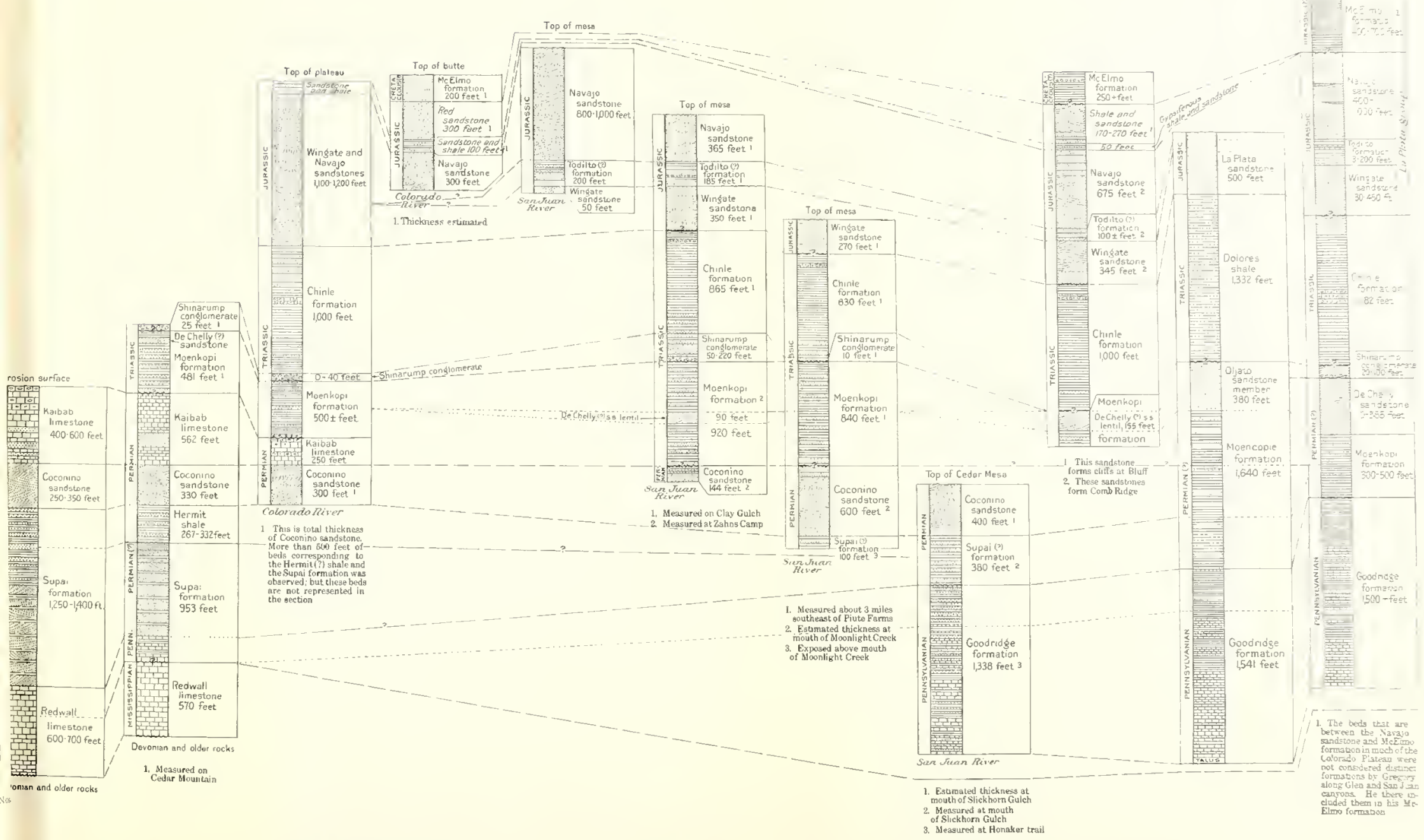

GENERALIZED COLUMNAR SECTIONS OF THE PALEOZOIC IND MESOZOIC ROCKS OF NORTHERN ARIZONA ANI) $\rightarrow O I T I E A T E R N$ UTAH 




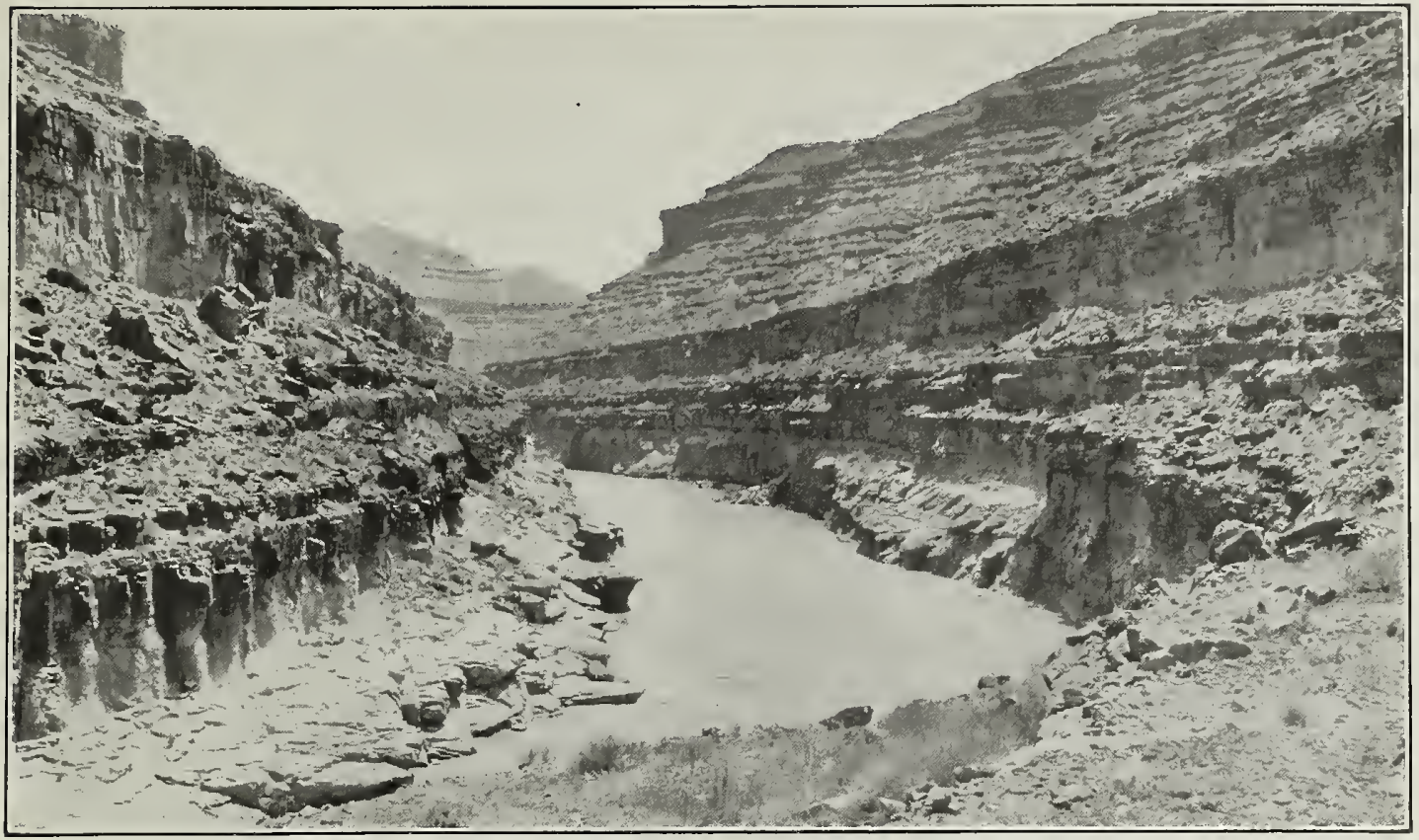

A. VIEW LOOKING DOWN SAN JUAN CANYON, UTAII, AT A POINT 9 MILES BY STREAM ABOVE IIONAKER TRAIL.

Canyon has been eut in Goodridge formation. Photograph by Robert N. Allen

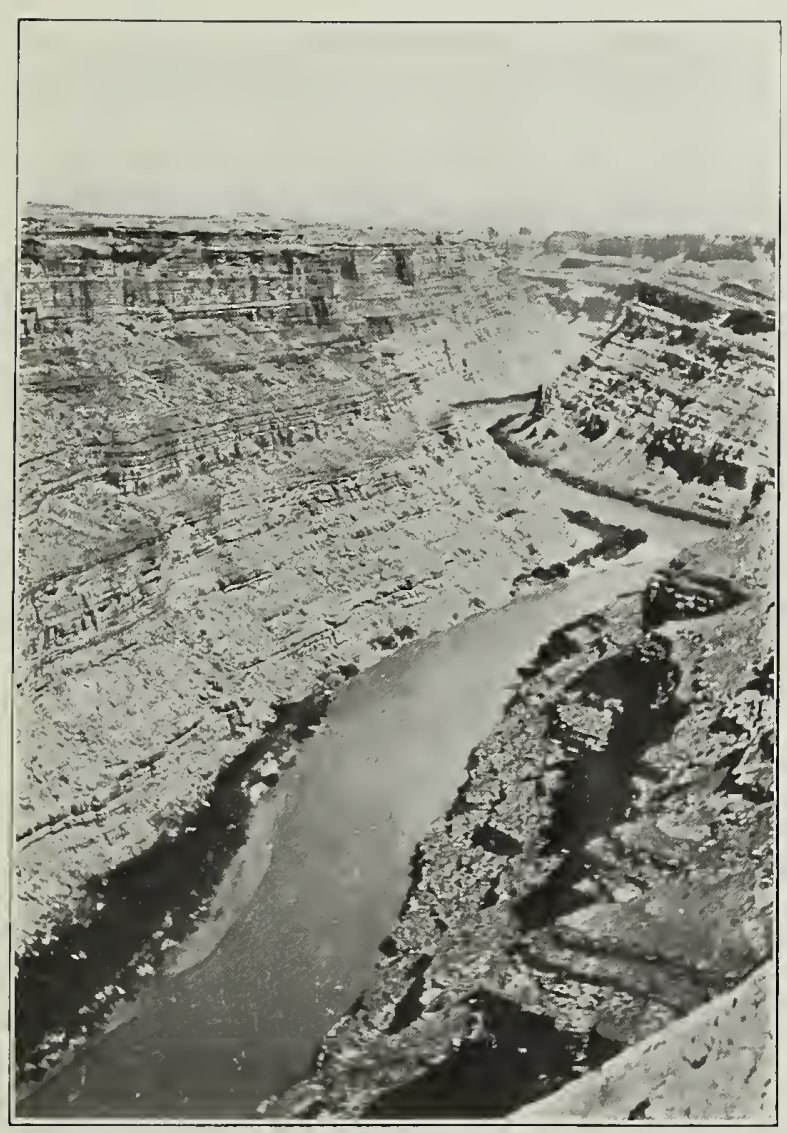

B. VIEW LOOKING DOWN GREEN RIVER TOWARD ITS JUNCTION WITH COLORADO RIVER, UTAII.

Canyon cut in Goodridge formation. Photograph by Sidney Paige.

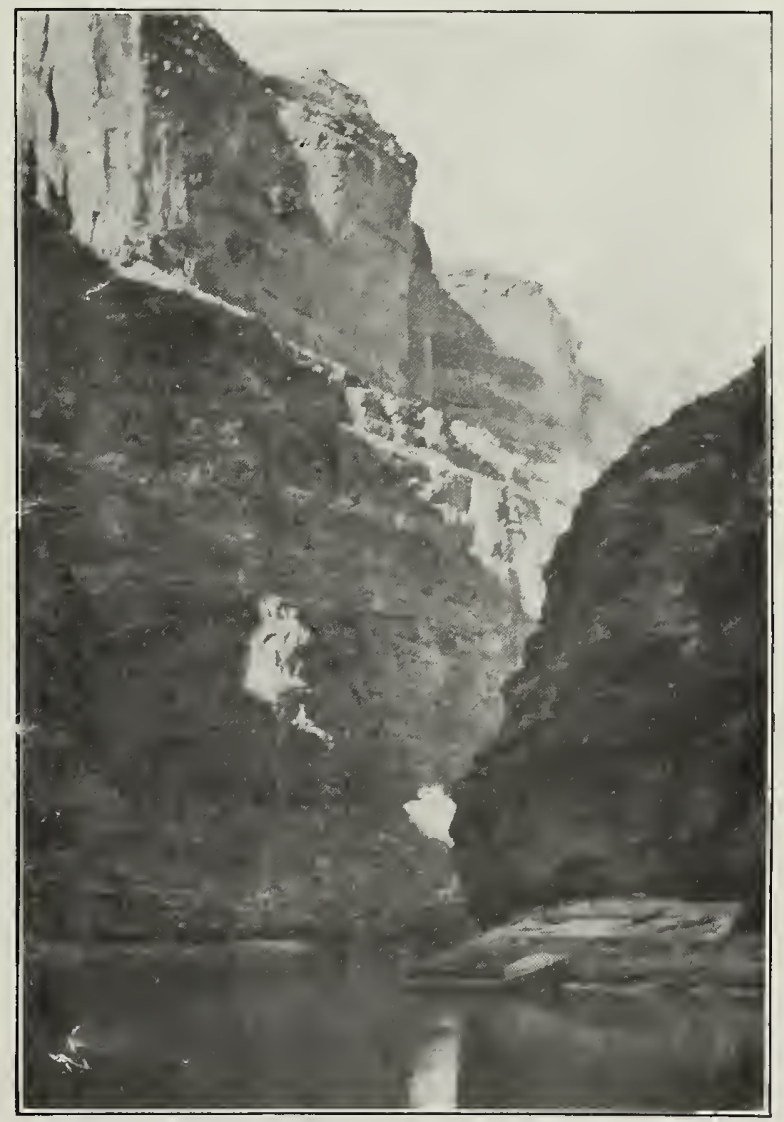

C. VIEW IN CATARACT CANYON OF THE COLORADO, UTAH.

Goodridge formation forms lower part of canyon walls and Coconino sandstone the upper part. These two formations are probably separated by beds that are equivalent to the
Supai (P) formation of the San Juan Canyon. Photograph by Sidney Paire. 


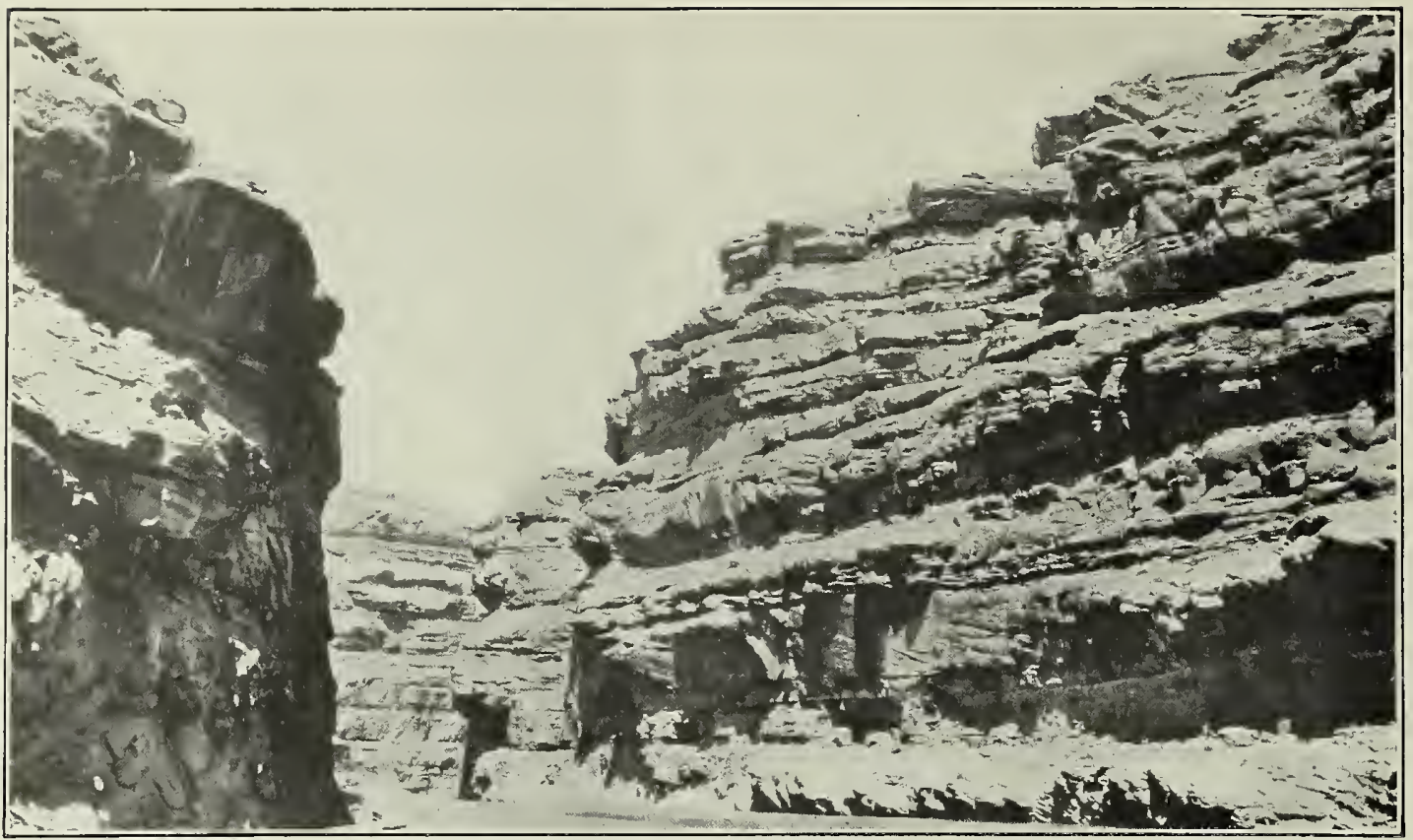

A. VIEW LOOKING DOWN SAN JUAN CANYON, UTAH, AT A POINT BETWEEN CLAY HILL CROSSING AND THE MOUTH OF MOONLIGHT CREEK.

Coconino sandstone forms canyon walls. Photograph by H. D. Miser.

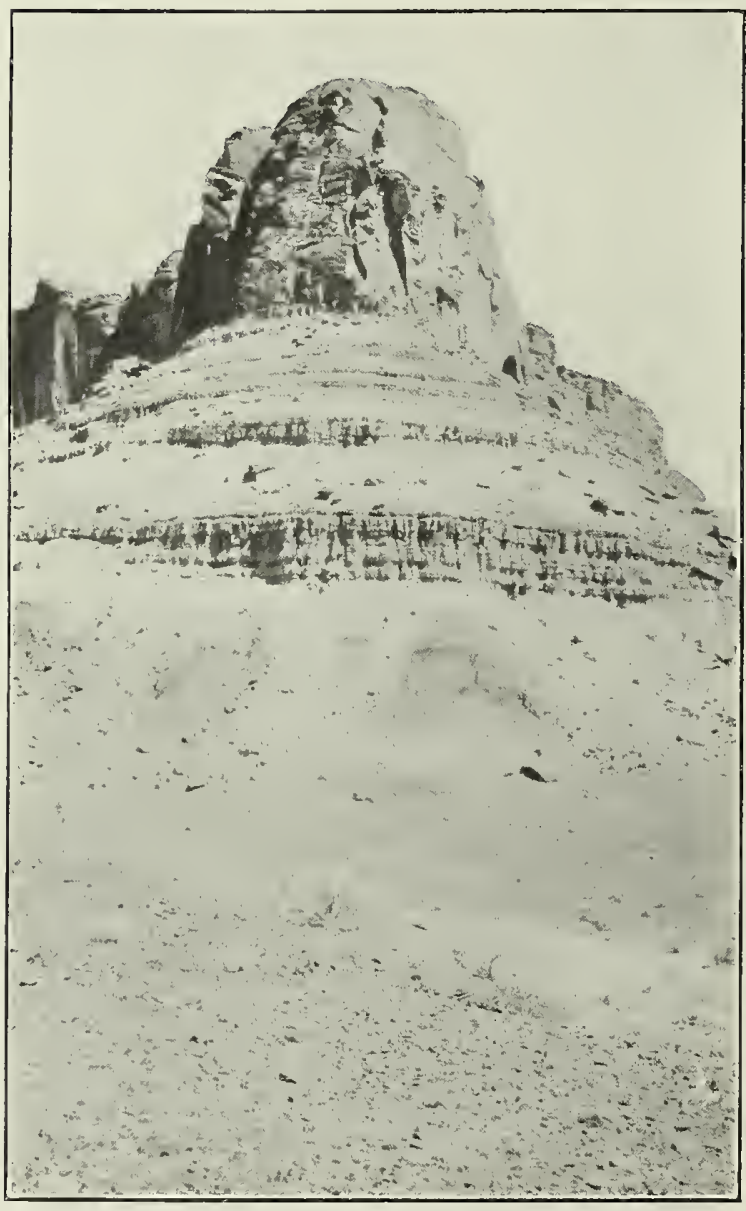

B. VIEW NEAR COLORADO RIVER 2 MILES BELOW MOUTH OF TRACHYTE CREEK, UTAH.

Showing Chinle formation, about 320 feet thick, capped by Vingate sandstone. Part of wide hench in foreground is on
Shinarunip conglomerate. Photograph by C. R. Longwell.

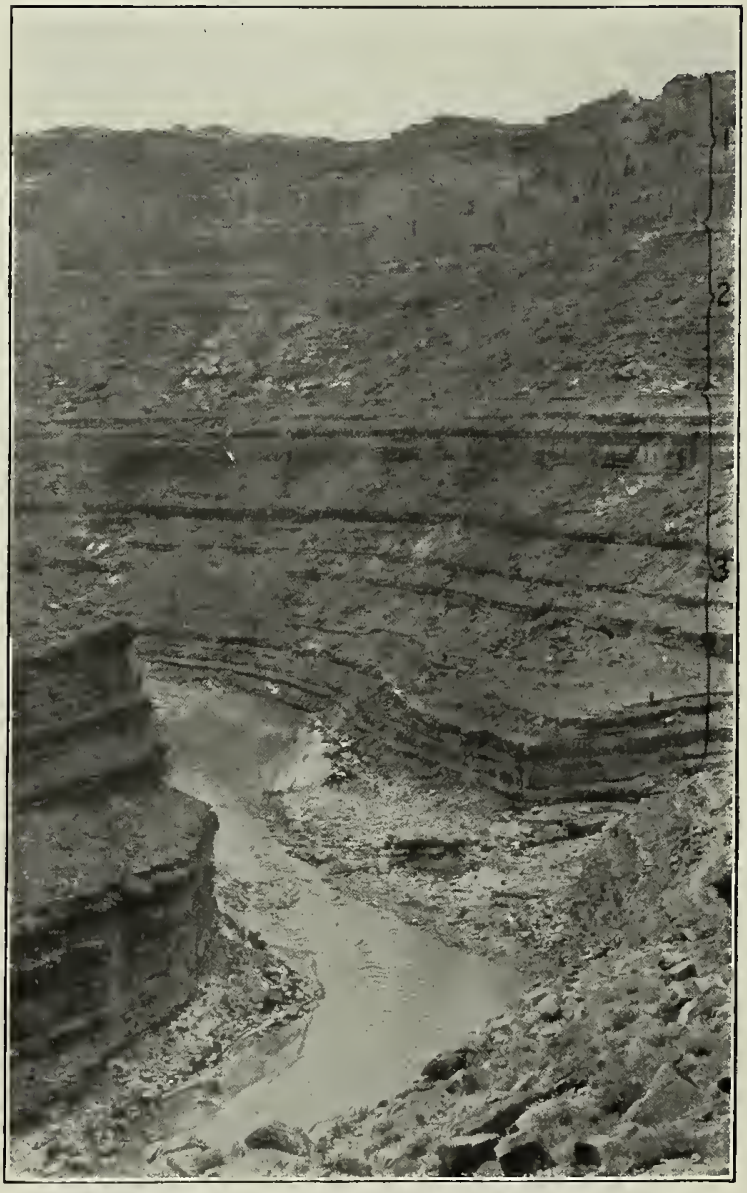

C. VIEW LOOKING DOWN SAN JUAN CANYON AT THE MOUTH OF SLICKHORN GULCH, UTAH.

1, Coconino sandstone; 2, Supai (?) formation; 3, Goodridge formation. 'The rapid is produced by a boulder bar at the mouth of Slickhorn Culch. l'hotograph by Robert N. Allen. 


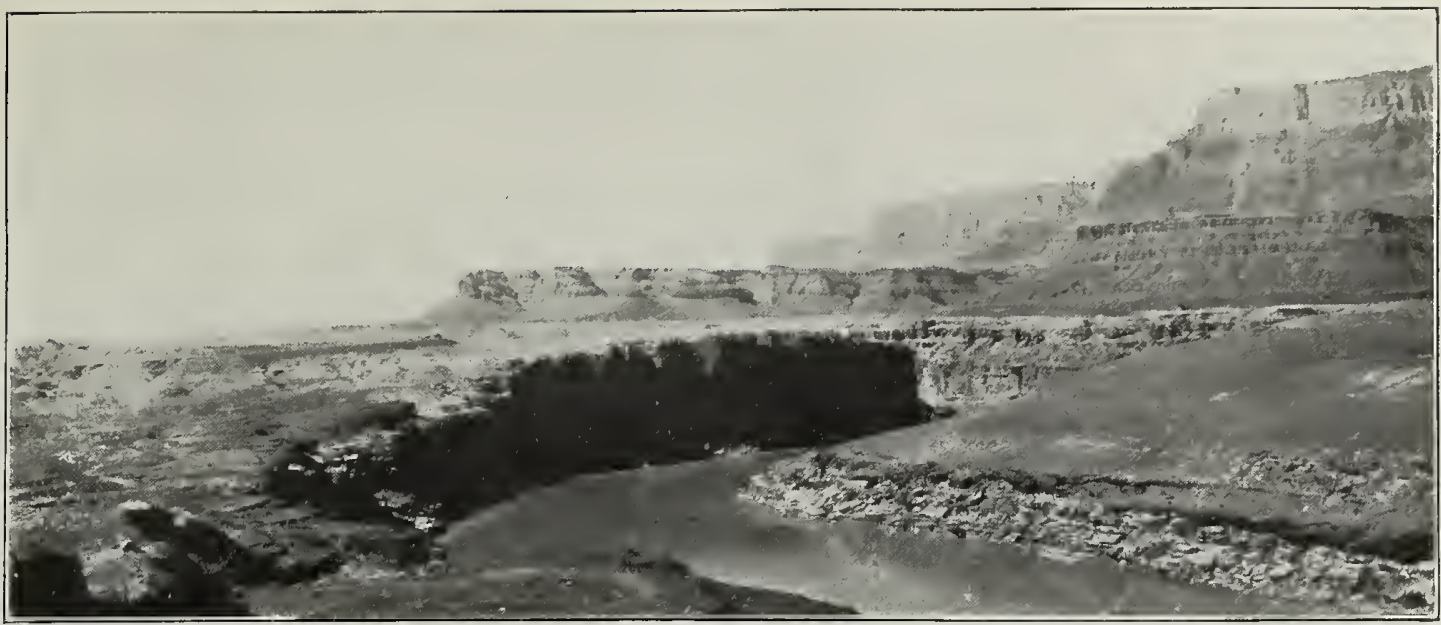

A. WEW LOOKING SOUTHWEST DOWN HEAD OF MARBLE CANYON FROM POINT NEAR LEES FERRY, ARIZ.

Platform in foreground is underlain by Kaibab linestone; next higher platform reveals the Moenkopi formation and is capped by Shinarump congloinerate; the high Vermition Cliffs, to the right, are formed by Wingate and Navajo sandstones, Chinle formation is exposed on steep slope below Vermilion Clifts. Photowraph by Kirk Bryan.

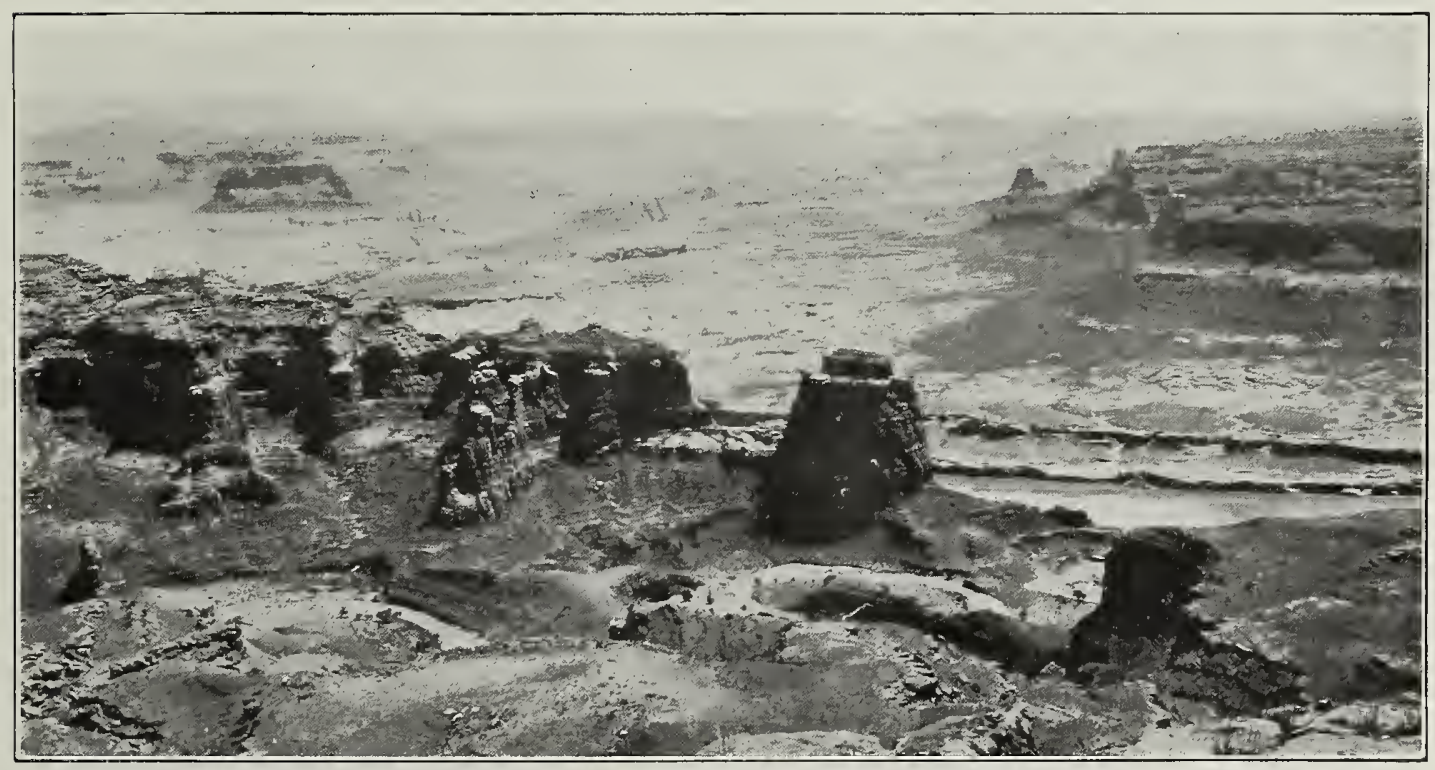

B. VIEW LOOKING UP COLORADO RIVER FROM A HIGH POINT NEAR THE MOUTH OF CRESCENT CREEK, UTAH.

Crescent Creek in foreground. The Colorado is deeply incised in the Coconino sandstone, which forms the lightcolored platform. Moenkopi formation in the foreground is stripped from this platform. Photograph by C. R. Longwell

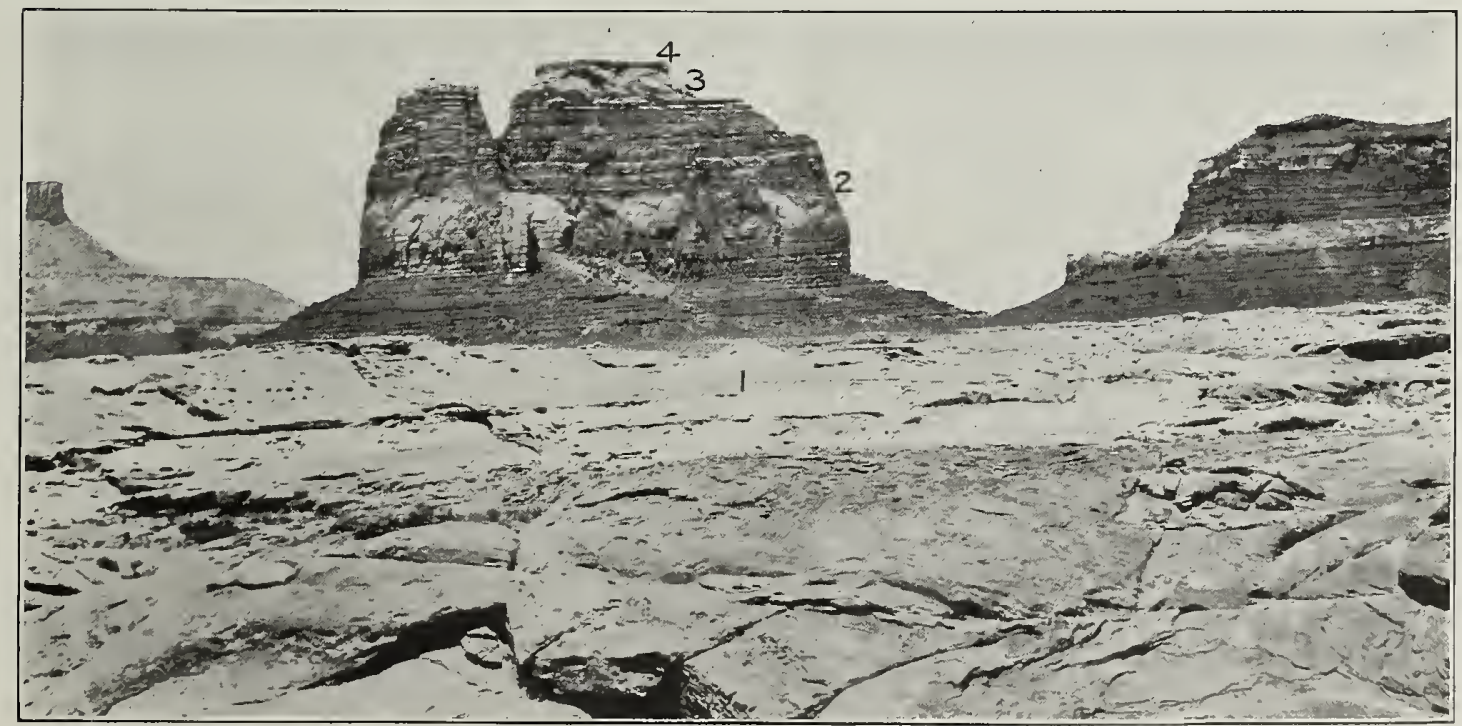

C. EROSION REMNANTS STANDHNG ON PLATFORM OF COCONINO SANDSTONE NEAR MOUTH OF FREMONT RIVER, UTAH.

1. Coconiao sandstone; 2, lower member of Moenkopi formation; 3, De Chelly (9) sandstone lentil of Moenkopi formation; 4, conglomerate at base of upper member of Moenkopi formation. Photograph by C. R. Longwell. 


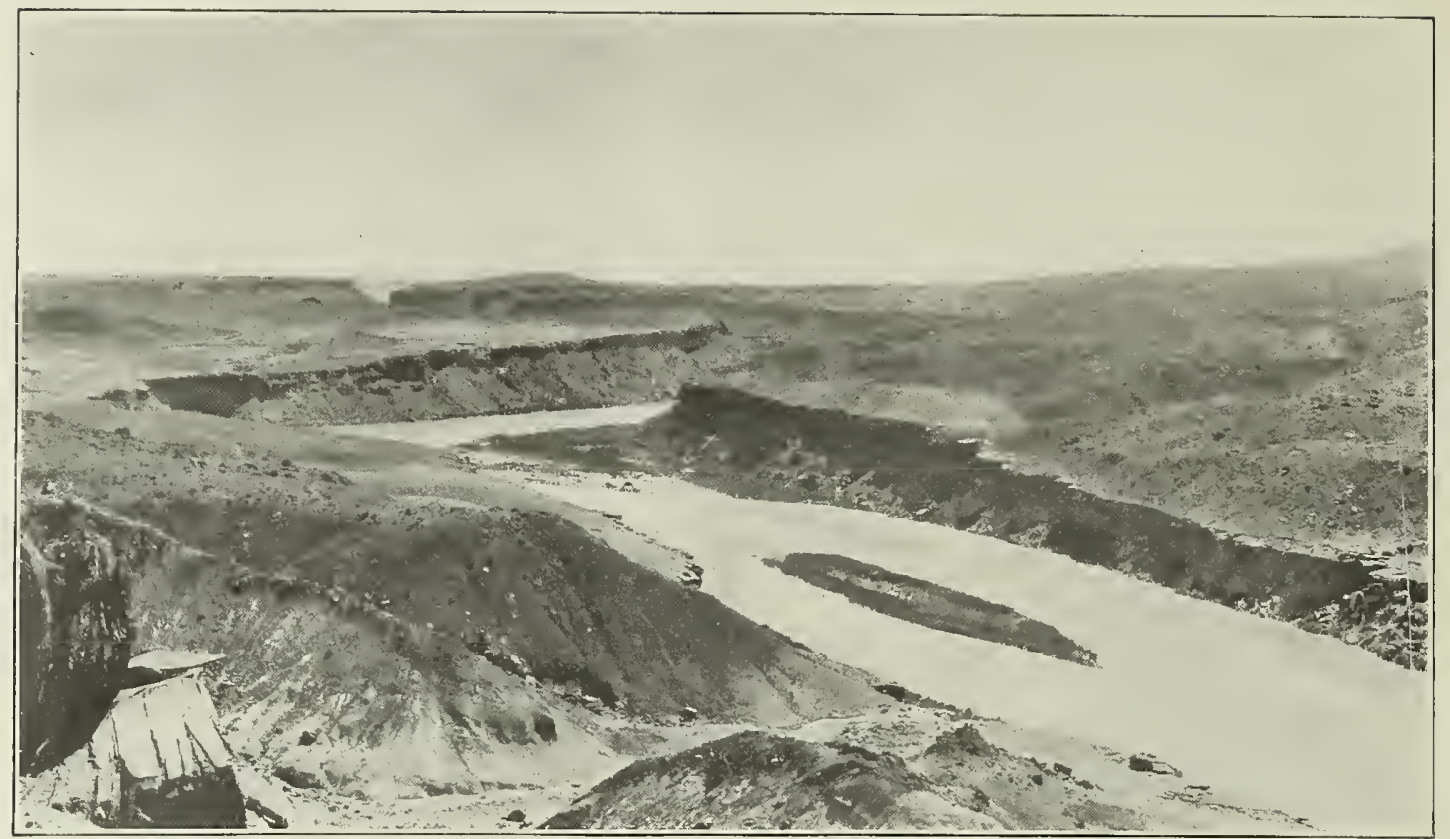

A. VIEW LOOKING UP SAN JUAN CANYON FROM POINT NEAR MOUTH OF CLAY GULCH, UTAH.

Platform is underlain by S.linarump congiomerate, but in foreground terrace gravels and landslide material rest on Shinarump. Moenkopi formation is exposed in lower part of canyon walls. Photograpl by Rol,cit N. Allen.

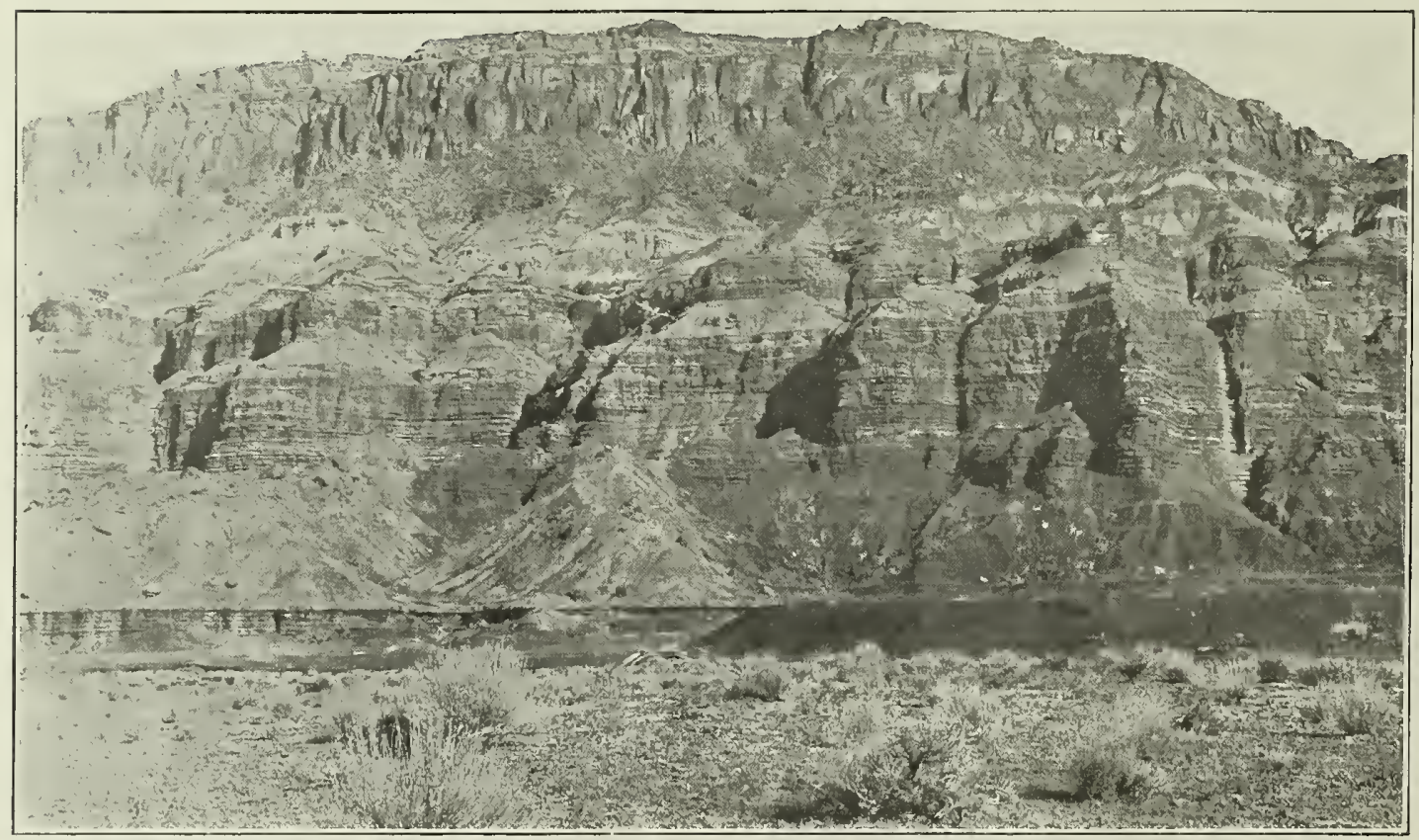

B. VHEW LOOKING WEST TOWARD HIGH MESA AT CLAY HILL CROSSING ON SAN JUAN RIVER, UTAH.

Coconino sandstone underlies level foreground; Moenkopi formation, next above, weathers wilh fluted edges; De Chelly (?) sandstone lentil of Moenkopi is absent; Chinle forms steep badland slope with dark and light lands; Wingate, Todilto (ग), and Navaio formations form clifls at top of mesa. Shinarump conglomerate is alsent. I'hotograph lyy Robert N. Allen. 


\section{CARBONIFEROUS SYSTEM.}

Goodridge formation. - The Goodridge formation, which has been described by Woodruff, ${ }^{14}$ is best exposed at the type locality on the Honaker trail in San Juan Canyon near Goodridge, where the canyon has been carved into it to a depth of 1,338 feet without revealing the base. It is of marine origin and consists of sandstone, sandy shale, and cherty limestone, with gray limestone predominating in the lower 500 feet and sandstone and shale in the upper portion. (See Pls. III, $A$, and IV, $C$.) Red is the most common color of the beds in the upper 700 feet. The base of the formation is nowhere exposed, and therefore its relation to older rocks is not known. A less complete section of the formation-about 1,000 feet-is exposed in another anticline east of Goodridge. About 1,500 feet of it is exposed in Cataract Canyon on the Colorado. (See Pls. II, III, $B$ and $C$.) A deep well drilled in the Circle Cliffs by the Ohio Oil Co. penetrated in its lower part 1,582 feet of white sandstone and limestone that may represent the Goodridge formation.

Fossils are abundant and are distributed throughout the type section from a horizon near the base to the top. G. H. Girty, who has studied the faunas, makes the following statement:

The Goodridge formation, as described by Woodruff, ${ }^{14}$ comprises two widely different faunas. The lower fauna, which contains almost no true Mollusca, changes abruptly, at bed No. 55 of his published section, to one that contains almost nothing else. The base of the bed as measured by Miser is 314 to 324 feet below the top of the formation. The character of the change suggests that it may not be as significant as the degree of the change might indicate.

The two sections that naturally invite comparison with the Goodridge are the San Juan section, Colorado, to the east, and the Grand Canyon section, to the west. [See PI. I.] As I suggested in 1912, the general faunal resemblances would tend to correlate the upper part of the Goodridge with the Rico formation in the San Juan region and with the upper part of the Redwall limestone [old usage of Redwall] in the Grand Canyon region. On the same grounds the lower part of the Goodridge would be correlated with the Hermosa formation of the San Juan, which underlies the Rico. In the Grand Canyon section, however, the lower part of the Goodridge has no equivalent that can at present be recognized, but it is closely related faunally to the Magdalena limestone of New Mexico.

Developments of the last ten years have brought about an assignment of the Rico formation to the Permian (?), while the upper part of the old Redwall limestone is referred to the Pennsylvanian and now included in the Supai formation. It is evident that the upper part of the

14 Woodruff, E. G., op. cit., pp. 80-85. $33371^{\circ}-23 \longrightarrow 2$
Goodridge can not be correlated with both these formations and yet these assignments be correct. An error evidently exists, but it can not at present be located. The correlations here adopted seem the natural ones, and it is thought better to continue them for the present and to leave adjustments of age determinations to a future day and more satisfactory evidence.

At present, therefore, the upper part of the Goodridge can not be assigned with assurance to any epoch, but the greater part of the formation is certainly Pennsylvanian. It is evident from Mr. Girty's remarks that any attempt to match the Goodridge with a part of the standard Grand Canyon section must be considered as tentative only. This fact should be borne in mind in connection with the columnar sections (Pls. I, II) offered in this paper.

Sandstone and limestone beds of the Goodridge formation supply the oil in the San Juan field, as noted by Gregory and Woodruff. Some of these oil-bearing beds are near the top of the formation, but others are much deeper, the lowest being 1,300 feet below the top. Oil seeps occur at several places along the bottom of the San Juan Canyon. The largest extends for $1 \frac{1}{4}$ miles above the mouth of Slickhorn Gulch, and the oil at this locality comes from westward-dipping beds along and near a fault about 520 feet below the top of the Goodridge.

Supai (?) formation.-The Goodridge formation in the San Juan region and in Cataract Canyon is overlain by red sandy shale and shaly sandstone. (See Pl. III, C.) Gregory notes that no definite unconformity is recognized at the top of the Goodridge,$^{16}$ but there appears to be a transition to the red beds above through limestone conglomerate that may represent a gradual change from marine to continental conditions. At the mouth of Slickhorn Gulch, on the west side of the San Juan oil field, these higher red beds are 380 feet thick. (See Pl. IV, C.) In view of their lithologic character and their position immediately beneath the Coconino sandstone, a possible correlation with Noble's Hermit shale is suggested; but in the absence of fossils the beds are correlated doubtfully with the upper part of Noble's Supai formation, which has a much wider known distribution than the Hermit shale. Woodruff and Gregory referred these red beds to the lower part of the Moenkopi formation, which is now recognized as Triassic. (See Pls. I and II.)

${ }^{16}$ Gregory, H. E., Geology of the Navajo country: U. S. Geol. Survey Prof. Paper 93, p. 21, 1917. 
In the head of Marble Canyon about 500 feet of red shale and sandstone containing beds of blue limestone in their lower part were observed beneath the Coconino sandstone. The highest of these beds may be equivalent to Noble's Hermit shale, but the lowest are probably equivalent to his Supai formation.

Coconino sandstone.-The Coconino sandstone has yielded no determinable fossils, but it is recognized in southern Utah by criteria other than its peculiar lithologic character. In Marble Canyon, southwest of Lees Ferry, Ariz., the sandstone is present in its normal position beneath the Kaibab limestone, which in turn is unconformably overlain by the Lower Triassic Moenkopi beds. In Circle Cliffs the same relations are seen but the Kaibab is much thinner than at Lees Ferry and localities farther west. In and about Cataract Canyon and on the San Juan the Kaibab is absent and the Moenkopi rests unconformably on a thick sandstone that has all the characteristics of the Coconino. Gilbert recognized this relation n'ear Cataract Canyon and referred to the sandstone as the "Upper Aubrey sandstone," the name used at that time for the Coconino in the Grand Canyon. (See Pls. I, II, IV, C, and $\mathrm{V}, B$ and $C$.)

The sandstone here called Coconino has been traced by B. S. Butler, ${ }^{17}$ F. L. Hess, ${ }^{18}$ H. E. Gregory, ${ }^{18}$ C. R. Longwell, and H. D. Miser practically the entire distance from Cataract Canyon to the San Juan oil field by way of White Canyon. The three large natural bridges in White Canyon are stated by Hess and Gregory to have been formed in this sandstone. On the San Juan the Coconino is exposed in a small area on the crest of an anticline at Zahns Camp, but farther upstream it is exposed over large areas, being the surface formation in the part of Moonlight Valley in which Train and Organ rocks are situated and also in the broad dissected plateau between the Clay Hills and the San Juan oil field. (See Pl. IV, $A$ and C.) The eastern part of the plateau is known as Cedar Mesa. Woodruff ${ }^{19}$ states that eastward from Cedar Mesa the sandstone grades completely into red sandy shale on the southeast side of the oil field. This shale and the equivalent sandstone were

17 Butler, B. S., The ore deposits of Utah: U. S. Geol. Survey Prof. Paper 111, pp 619-620, 1920.

18 Oral communication.

19 Woodruff, E. G., op. cit., p. 86. included by Woodruff ${ }^{20}$ and Gregory ${ }^{21}$ in their Moenkopi formation. (See Pls.' I and II.)

The sandstone is massive and highly crossbedded, and its color is creamy white, though on Cedar Mesa much of it is tan. The grains are fine to medium in size, and as a rule the cement of calcium carbonate is sufficient to make the rock fairly firm, although in places it is friable. The greatest thickness observed is in Cataract Canyon, where it measures nearly 1,000 feet. In the Circle Cliffs only the top of the formation can be seen, but the deep well mentioned above penetrates white sandstone hundreds of feet thick immediately beneath the Kaibab and then passes through beds that are probably the equivalent of the Supai (?) formation. The Coconino, as well as most of the supposed Supai there, consists of white sandstone, so that these two formations can not be separated in the well log. Their combined thickness is 1,550 feet. Near the mouth of Moonlight Creek on the San Juan the thickness of the Coconino is about 600 feet; at the mouth of Slickhorn Gulch, also on the San Juan, it is about 400 feet; at Lees Ferry it is 300 feet; in the Grand Canyon it ranges from 250 to 350 feet; and to the west it gradually decreases, ${ }^{22}$ the formation losing its identity in southern Nevada. ${ }^{23}$ Thus it is evident that the sandstone thickens consistently toward the northeast in the area of its known distribution.

Kaibab limestone.-Typical Kaibab limestone consisting of white and yellow dolomite and limestone with numerous chert nodules is present in the Circle Cliffs, but its thickness is only 150 feet, as compared with 250 feet at Lees Ferry, 400 to 600 feet in the Grand Canyon, ${ }^{24}$ and 1,000 feet in northwestern Arizona and southwestern Utah. ${ }^{25}$ (See Pl. V, A.) It is not found in Cataract Canyon, in the Henry Mountains, ${ }^{28}$ or along San Juan River. (See Pls. I and II.) Thus it appears to thin progressively toward the northeast, with the thickening 20 Woodrufi, E. G., op. cit., pp. 86-87.

${ }^{21}$ Gregory, H. E., Geology of the Navajo country: U. S. Geol. Survey Prof. Paper 93, pp. 29-30, 1917.

${ }_{22}$ Reeside, J. B., and Bassler, Harvey, Stratigraphic sections in southwestern Utah and northwestern Arizona: U. S. Geol. Survey Prof. Paper 129, pp. 57-58, 1922.

${ }^{23}$ Longwell, C. R., Geology of the Muddy Mountains, Nev., with a section to the Grand Wash Cliffs in western Arizona: Am. Jour. Sci., 5th ser., vol. 1, p. 47, 1921 .

${ }_{24}$ Noble, L. F., The Shinumo quadrangle, Grand Canyon district, Ariz.: U. S. Geol. Survey Bull. 549, p. 70, 1914.

25 Reeside, J. B., and Bassler, Harvey, op. cit., pp. 69-76.

${ }^{26}$ Gilbert, G. K., Geology of the Henry Mountains, p. 4, U. S. Geog. and Geol. Survey Rocky Mtn. Region, 1880. 
of the Coconino sandstone in this direction, suggesting lateral gradation of the limestone into the sandstone at the top of the Coconino. It is probable, however, that a large part of the thinning is due to beveling during the erosion interval recorded by the unconformity at the base of the Triassic. This problem is of considerable interest, especially to the paleogeographer, for under the first interpretation the Kaibab shore line certainly lay at no great distance east of the Circle Cliffs, whereas the alternate explanation permits a much greater extension of the Kaibab sea eastward. Study of the Kaibab faunas gives weight to the suggestion that pre-Triassic erosion beveled progressively eastward, for the fauna found in the Circle Cliffs is of the "normal Kaibab" type ${ }^{27}$ and not the upper "Bellerophon limestone" fauna. Therefore it is probable that the Kaibab present in the Circle Cliff's is lower stratigraphically than the top of the Kaibab in the Grand Canyon and the "Bellerophon bed" in the Park City formation of the Uinta country.

\section{EROSION INTERVAL.}

A significant unconformity separates the Paleozoic and Mesozoic sections. There is no perceptible divergence between beds, but an unmistakable surface of erosion lies beneath the Moenkopi formation wherever it has been studied in Arizona, Utah, and Nevada. The unconformity is particularly well shown near Cataract Canyon and about the mouth of Fremont River, where the top of the Coconino sandstone forms wide structural platforms. Recent erosion has stripped away the soft Triassic sediments, and the more resistant Coconino preserves large areas of the preTriassic erosion surface almost unchanged, with patches of the basal conglomerate of the Moenkopi still adherering to it here and there in the shallow valleys and rounded divides. Farther back from the main streams recent canyons are cut through the contact, revealing it as a distinct wavy line, overlain by conglomerate in which all the pebbles are of sandstone.

\section{TRIASSIC SYSTEM.}

Moenkopi formation.-The Moenkopi formation, of Lower Triassic age, comprises thick beds of shale and sandstone that lie unconformably on

\footnotetext{
${ }^{27}$ See Reeside, J. B., and Bassler, Harvey, op. cit., pp. 66-67.
}

the Permian rocks and are at most places unconformably overlain by the distinctive Shinarump conglomerate. As thus defined the Moenkopi consists of several members, which vary considerably in character and thickness from one locality to another. The total thickness ranges from 304 feet in the Circle Cliffs to 920 feet south of the Henry Mountains and along San Juan River. No marine fossils have been reported from the formation in southern Utah, but the lower beds exhibit a regularity and a uniformity of texture that suggest deposition in a large body of water. Farther west and southwest, in Arizona, southern Nevada, and southwestern Utah, the lower part of the formation is clearly of marine origin but the upper part is unmistakably of continental origin.

Along the San Juan the Moenkopi consists principally of red sandy shale and earthy sandstone, with a little gypsum. (See Pl. VI, B.) South and southwest of Piute Farms, on the river, a thin bed of cream-colored sandstone is found near the middle of the formation, and this layer thickens gradually toward the south, developing into a massive cross-bedded member which in Train Rock has an estimated thickness of about 200 feet. This sandstone is apparently the same as the sandstone in southeastern Utah called De Chelly by Gregory. He treated the De Chelly as a separate formation, because in most of the region he studied south of the San Juan he found it above Moenkopi shales and immediately underneath the Shinarump conglomerate. He also found that the "Oljato sandstone" of Woodruff is made up of the De Chelly and the Shinarump. (See Pl. I.) The De Chelly sandstone, according to Gregory, is present on the east side of the San Juan oil field, where it is red and thins out toward the north. He also states that the Shinarump conglomerate, wherever it is present on the east side of the oil field, rests on the De Chelly sandstone. It appears probable, therefore, that the upper shales of the Moenkopi were entirely removed in part of the Navajo country by pre-Shinarump erosion. An alternate hypothesis might be that these upper shales are replaced toward the south by the thickening of the De Chelly sandstone.

The sandstone that is here tentatively correlated with the typical De Chelly saridstone of northeastern Arizona disappears entirely near 
Piute Farms and Clay Hill Crossing on the San Juan, and it was not recognized in sections for 25 miles north of Clay Hill Crossing.

Along Colorado River below Cataract Canyon the Moenkopi again shows three distinct divisions. The lower division, about 400 feet thick, consists of red and maroon sandstone and sandy shale in regular beds, with a gray conglomerate layer at the base. Shaly beds predominate near the bottom of the section, forming a slope that steepens upward and merges into a cliff made of the more resistant red sandstone. In most sections this cliff is capped with a layer of cross-bedded gray or cream-colored sandstone, ranging in thickness from a few inches to 60 feet. On account of its persistence and its striking contrast with the underlying red beds this member forms an excellent horizon marker. Its stratigraphic position and lithologic character suggest its correlation with the De Chelly (?) lentil on the San Juan.

The upper division of the Moenkopi along this portion of the Colorado consists chiefly of chocolate-colored, red, and gray shale and sandstone ranging in thickness from 350 to nearly 400 feet. Thin-bedded sandstone predominates in the lower part, and the proportion of sandy shale increases upward. The division as a whole has a weak topographic expression, forming a concave slope below the Shinarump cliff. Thin flaggy sandstone layers with strong ripple marks and current marks recur at short intervals in the section. Lenticular layers of cross-bedded sandstone 15 feet in maximum thickness are also common and form the roofs of many old cliff dwellings that are built in reentrants at horizons of shale. All the sandstone beds show evidence of strong fluviatile action, and the shales were probably deposited on flood plains or in shallow temporary lakes. A persistent layer of conglomerate, from a few inches to 25 feet thick, forms the base of the upper division and fills erosion channels in the De Chelly (?) sandstone. This distinct erosional unconformity within the Moenkopi is seen in all sections along Colorado River and its tributaries from Cataract Canyon to Red Canyon, where the gradual westward dip carries the formation below the surface. (See Pls. V and VII, A.)

Near Lees Ferry, Ariz., the Moenkopi consists of about 500 feet of red sandy shale and thin-bedded sandstone with seams of gypsum, but 50 miles to the south it has numerous thick beds of red and buff sandstone. Near Jacobs Pools, 25 miles west of Lees Ferry, 12 feet of greenish-yellow sandy shale and 12 feet of yellow sandy and gypseous limestone occur at the top of the formation.

In the Circle Cliffs the Moenkopi consists of 475 feet of chocolate-colored and yellow shale and sandstone with a few thin beds of hard limestone near the top. No gypsum was seen in the formation in this area or along the Colorado, but secondary veins of gypsum traverse the Moenkopi shales near Fruita, in Wayne County, Utah. Only a little gypsum occurs in the Moenkopi of the San Juan region and near Lees Ferry, and the general scarcity of the mineral in the entire region under discussion is noteworthy in view of the high content of primary and secondary gypsum found in both the marine and continental phases of the Lower Triassic in Arizona, southern Nevada, and southwestern Utah.

From the foregoing account and from the columnar sections (Nos. 6 to 9 on Pl. I) it is apparent that the Moenkopi of Woodruff and Gregory in the San Juan region includes not only the typical or true Moenkopi but also the Coconino sandstone and the Supai (?) formation.

Shinarump conglomerate.-The remarkable persistence of the Shinarump conglomerate has excited the wonder of geologists who have studied Triassic sections in different parts of the Colorado Plateau. Within the area under discussion it is generally present at the base of the Upper Triassic, lying on the eroded upper surface of the Moenkopi formation. It is a massive unit of coarse cross-bedded sandstone, in which are interspersed lenses of conglomerate that contain small rounded pebbles of chert, quartzite, and silicified wood. Silicified logs are abundant, and many plant impressions were seen on bedding surfaces. The average thickness of the unit is probably less than 50 feet, but it fills depressions in the underlying beds and at some localities attains a thickness of more than 200 feet. Near the mouth of Nokai Creek on the San Juan the thickness is 220 feet.

The position of the Shinarump conglomerate between two thick shaly formations gives it a strong topographic expression on the sides of 
valleys, the edge forming a prominent cliff in front of a stripped bench and above a pronounced slope. (See Pls. IV, $B ; \mathrm{V}, A ; \mathrm{VI}$, $A$; and VII.) The formation is made still more conspicuous in many sections by its dark color on exposed edges; for although the fresh sandstone is ordinarily gray, it appears to acquire an especially dark coat of desert varnish to with long exposure. This characteristic is so pronounced that the Shinarump is often referred to as "the black layer" by prospectors and others along the Colorado. Deposits of carnotite in the formation have been mined at several localities.

The exact conditions under which the Shinarump was deposited have been the subject of much discussion, and no conclusion appears to be generally accepted. Whatever the conditions were, it is evident that they must have been almost uniform over a very wide region, for in its essential characteristics the formation differs little in all the sections studied in Utah, Arizona, and Nevada. The uniformity extends even to its thickness, for the total section rarely exceeds 200 feet, and this maximum applies to very small areas. The lenticular and cross-bedded structure indicates the action of shifting streams with fluctuating volume, and the uniformly small thickness evidently indicates a nearly even surface with slight elevation. It is not probable that the region was a desert, for the abundance of silicified wood found in all sections testifies to a climate suitable for the growth of large trees.

Chinle formation.-The Shinarump is believed to be the "basal conglomerate" of the Upper Triassic, for the finer sediments of the Chinle formation in this region follow without any apparent break. Thick beds of marly shale, gray, pink, lavender, yellow, and variegated, form the most conspicuous part of the Chinle. Fine-grained sandstone, cherty limestone, and a few conglomeratic beds are intercalated with the shale. Large silicified logs are found in sandstone layers at several horizons, and there are other indications that the entire deposit is of continental origin. Along the San Juan the thickness ranges from 800 to 1,000 feet, and at Lees Ferry it is about 1,000 feet thick, but it is much thinner to the north, averaging 300 feet along the Colorado above the Waterpocket Fold and 450 feet west of the Waterpocket Fold. This thinning may be due $33371^{\circ}-23-3$ in part to pre-Jurassic erosion, for an erosional unconformity at the top of the Chinle is generally recognized, especially in the northern localities, although it does not appear to be profound.

Wherever the Chinle is exposed over areas of considerable size it gives rise to badland topography. Along the sides of valleys it forms long slopes, broken by low steps at horizons of sandstone or limestone layers. (See Pls. IV, $B$; V, $A$; VI, $B$; VII; and VIII, $B$.)

Limestone is found in the upper part of the formation in beds that range from a few inches to 2 feet in thickness, intercalated with limy shales. The limestone is dense and hard and contains an abundance of chert in nodules or lenses. Layers of intraformational limestone conglomerate are not uncommon. In most places the limestone beds are thin and are limited to a section not exceeding 30 feet in thickness, but at a few localities the individual layers average nearly 2 feet in thickness and make up fully half of a section 50 or 60 feet thick. Sandstone increases in amount toward the top of the formation.

\section{JURASSIC SYSTEM.}

General features.--Red, brown, tan, and gray sandstones of Jurassic age form the most prominent outcrops in the area under consideration. The units were traced almost continuously, and their relations for this portion of the plateau were determined without question. There still exists some degree of doubt as to the proper terminology to be applied in the Jurassic section, however, and the reasons for this uncertainty will be discussed briefly.

In the eastern part of the Navajo country Gregory recognized three Jurassic formations, ${ }^{28}$ which he thought were equivalent to the La Plata sandstone of southwestern Colorado. For the lowest unit he adopted Dutton's term Wingate sandstone, considering it identical with the section in the Zuni Plateau, ${ }^{29}$ to which this narne had been applied, and he called the upper formation the Navajo sandstone. In western New Mexico and eastern Arizona these two thick, cross-bedded formations are separated by beds of hard limestone and limy shale, at no place aggregating a

${ }_{28}$ Gregory, H. E., Geology of the Navajo country: U. S. Geol. Survey Prof. Paper 93, pp. 52-59, 1917.

${ }_{29}$ Dutton, C. E., Mount Taylor and the Zuni Plateau: U. S. Geol. Survey Sixth Ann. Rept., pp. 136-137, 1885. 
thickness of more than a few feet, but so persistent that they were recognized as a distinct unit and named the Todilto formation, from Todilto Park, N. Mex. In his reconnaissance survey Gregory was not able to trace the Todilto continuously to the west, but along the San Juan and in the vicinity of Navajo Mountain he recognized a distinct threefold division that appeared to correspond to the three formations observed farther east. The middle unit along the San Juan contains more sandstone than the typical Todilto, but limestone and limy shale are present at numerous places, and the sandstone formations above and below appear to be identical with the Navajo and Wingate of western New Mexico. Accordingly, Gregory applied the name Todilto to the middle unit tentatively, realizing that the correlation was not certain but only very probable. ${ }^{30}$ His Wingate and Navajo of the western Navajo country correspond respectively to Powell's Vermilion Cliff and White Cliff sandstones in the region north of the Grand Canyon and Marble Canyon, but no intervening formation is recognized in that region.

Emery worked with Gregory in the eastern part of the Navajo country and later made a survey of the Green River Desert, east of the San Rafael Swell, where he recognized three distinct Jurassic formations and applied to them Gregory's names Wingate, Todilto (?), and Navajo. ${ }^{31}$ The Todilto (?) of Emery contains fossils and is known to be at the horizon of the marine Jurassic. He noted an apparent threefold division of his Wingate in different sections, the middle member consisting of thinbedded sandstone and shale; but the height of these thin beds above the base of the Wingate varies at different localities, and therefore he believed that the beds were lenticular and did not represent a constant horizon. Later work, however, indicates that the beds occur at a definite horizon and that the variation in height above the base of the Wingate merely represents a variation in thickness of that formation, perhaps due in part to the unconformity at the top of the Chinle. The thinbedded unit was traced by Mr. Moore along the San Rafael Swell and the Waterpocket Fold,

${ }^{30}$ Gregory, H. E., op. cit., pp. 55-56.

s1 Emery, W. B., The Green River Desert section, Utah: Am. Jour. Sci., 4th ser., vol. 46, pp. 551-577, 1918. and other contributors to this report followed the beds continuously in other parts of the region, tracing them to the San Juan and to Rainbow Bridge and other localities where the beds form the unit correlated with the Todilto by Gregory. (See Pl. II.) It appears, therefore, that Gregory's usage has priority and should be retained for the present. It remains for future field work to determine the exact horizon of the Todilto at the type locality. If Gregory's tentative correlation along the San Juan should prove to be correct, then his terminology should be kept permanently and new names should be given to the formations designated Todilto (?) and Navajo by Emery. If the type Todilto is found to be at the horizon of the marine Jurassic, then Emery's tentative usage of the name will be established; but in that case his use of the names Wingate and Navajo should be reconsidered, for it appears that the name Navajo might well be retained for the sandstone that is typically exposed in Navajo Canyon and at Navajo Mountain, and the series of thin beds beneath it (Gregory's Todilto of the San Juan) deserves a new formation name.

In the following descriptions the three names are used in Gregory's sense, with the reservation suggested above regarding the Todilto. Emery's Todilto (?) will be referred to as "gypsiferous shales and sandstones" and his Navajo will be designated "varicolored sandstones and shales." Gregory, during field work since the publication of his reports on the Navajo country, has recognized these two units but has applied only temporary field names to them.

Wingate sandstone.-The Wingate sandstone is the most conspicuous cliff-maker in the region. (See Pls. IV, $B$; V, $A$; VI, $B$; VII, $A$; and VIII.) It is from 250 to 500 feet thick, and commonly the greater part of the total thickness appears as a single massive unit, which is cut by vertical joints and presents an impassable wall at the top of Chinle slopes. In some sections the lowermost beds are lenticular, in part conglomeratic, and apparently fill slight depressions in Chinle shale. These lower beds are obviously waterlaid. The massive, cliff-making portion, which averages about 300 feet in thickness, has indistinct and discontinuous bedding and is cross-bedded on a large scale. These structural characteristics, 


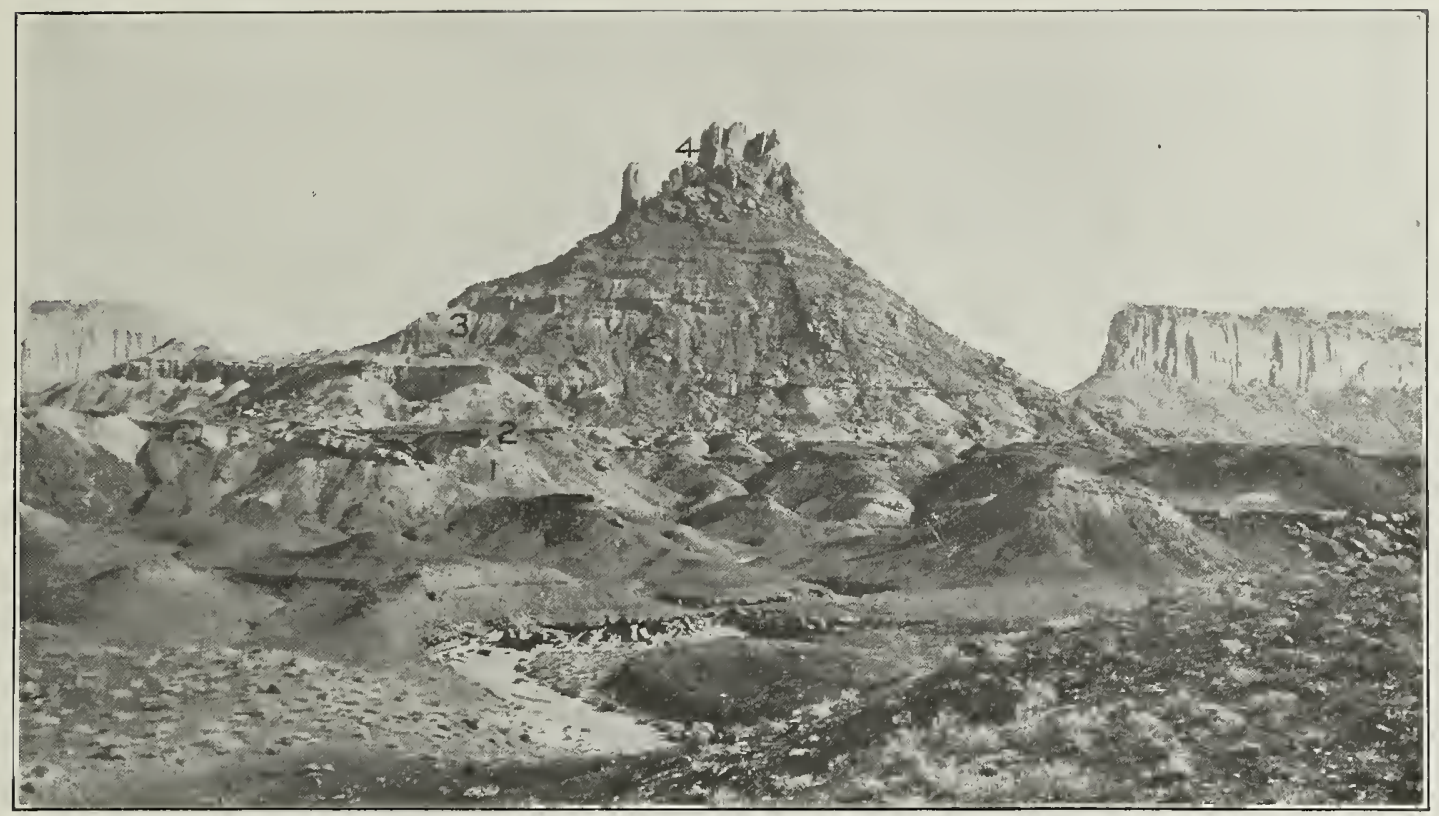

A. CASTle bUtTe, NeAr mouth of reD CANyon, utall. 1, Shale of upper member of Moenkopi formation; 2, Shinarump conglomerate; 3, Chinle formation; 4, Wingate

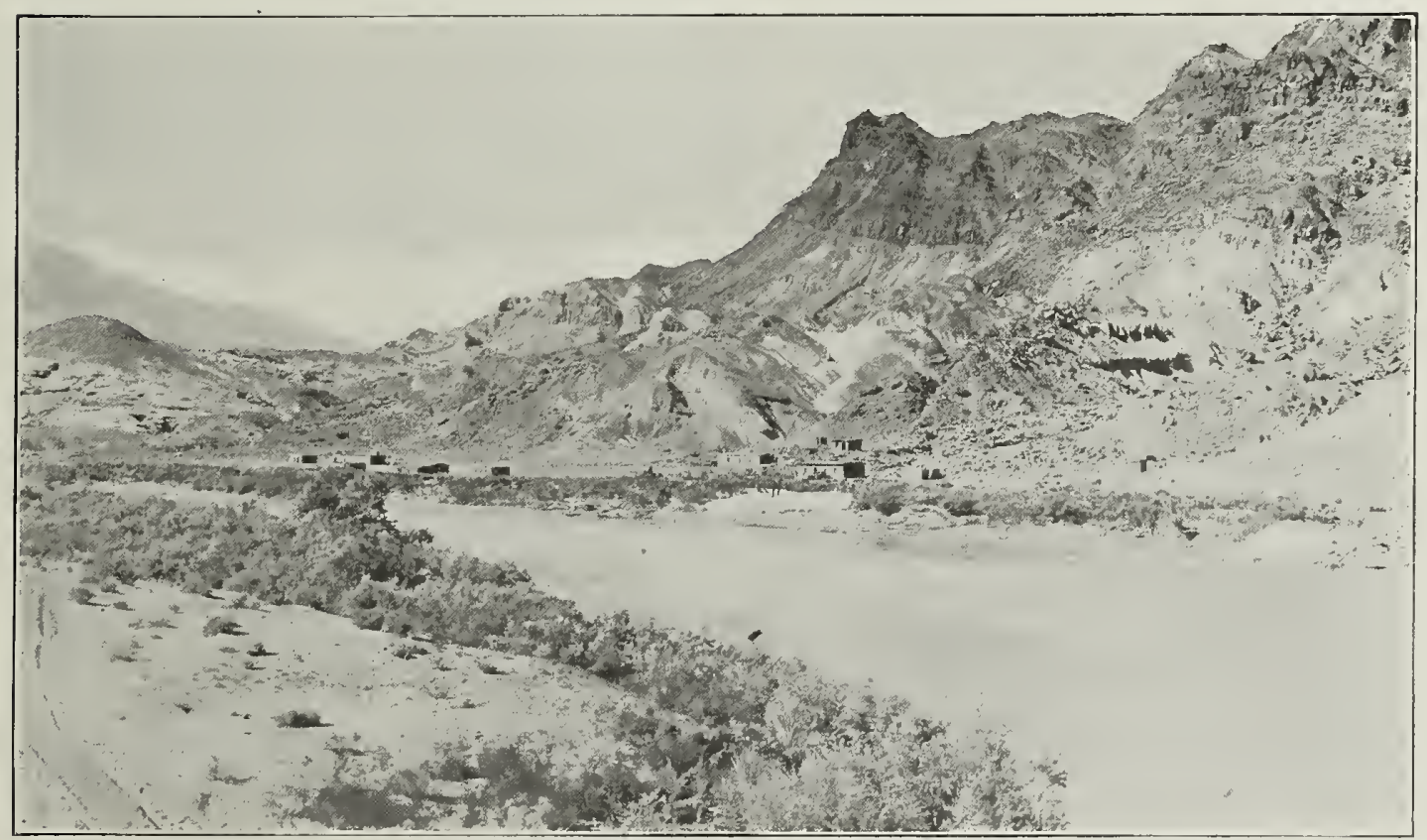

B. VIEW LOOKING NORTI ACROSS COLORADO RIVER AT LEES FERRY, ARIZ. Smath rounded knoll to left stands on Shinarump conghomerate, which dips east. All the higher bels to the right
form entire thickness of Chinle formation, Vermilion Clits in left background. I'holograph by Robert $\mathrm{N}$.
Allen. 


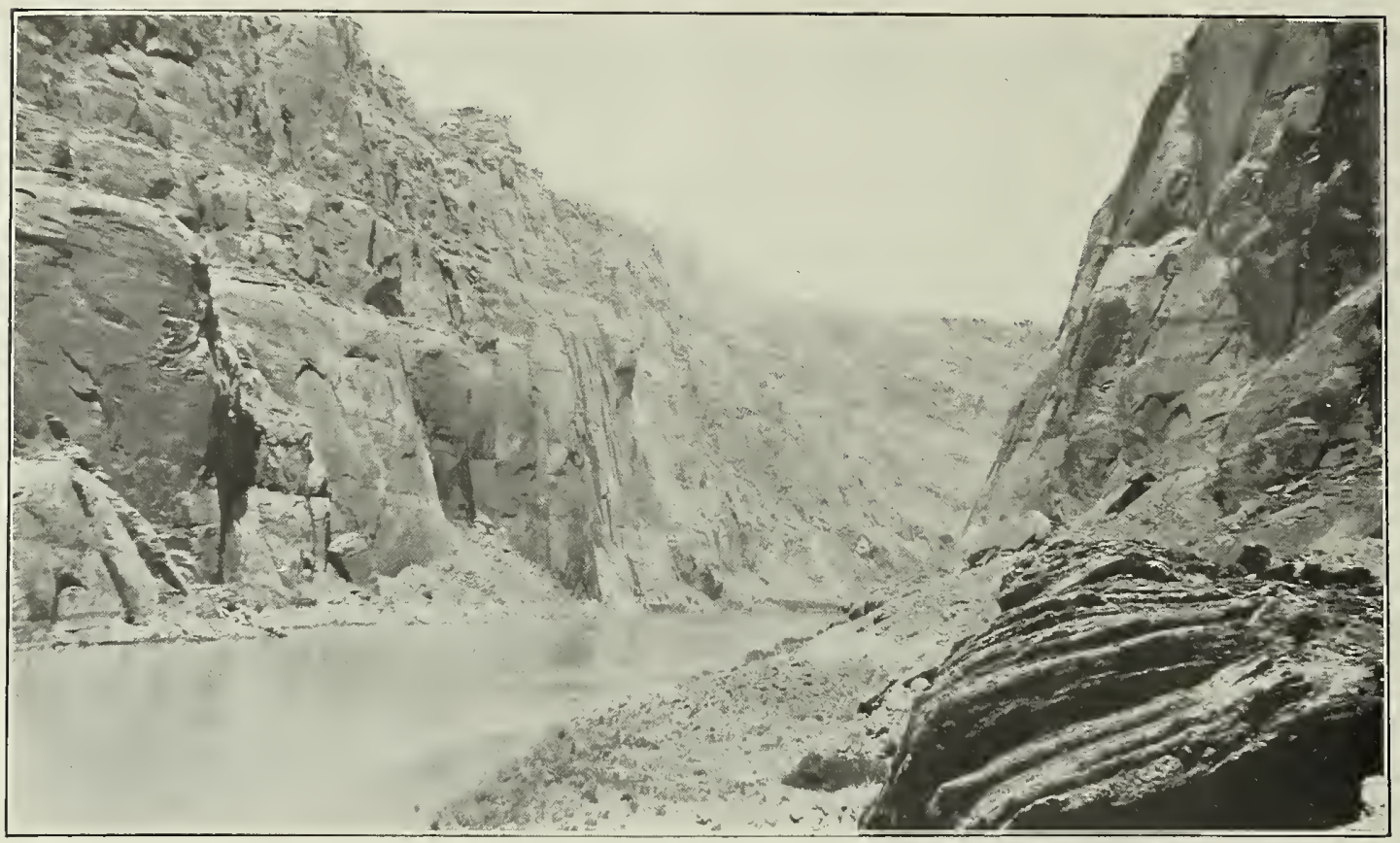

A. VIEW LOOKING NORTHWEST UP COLORADO RIVER TOWARD PROPOSED DAM SITE NEAR LEES FERRY, ARIZ.

Canyon walls are formed by Wingate and Navajo sandstones. Todilto (?) formation is apparently absent. Photograph by Kirk Bryan.

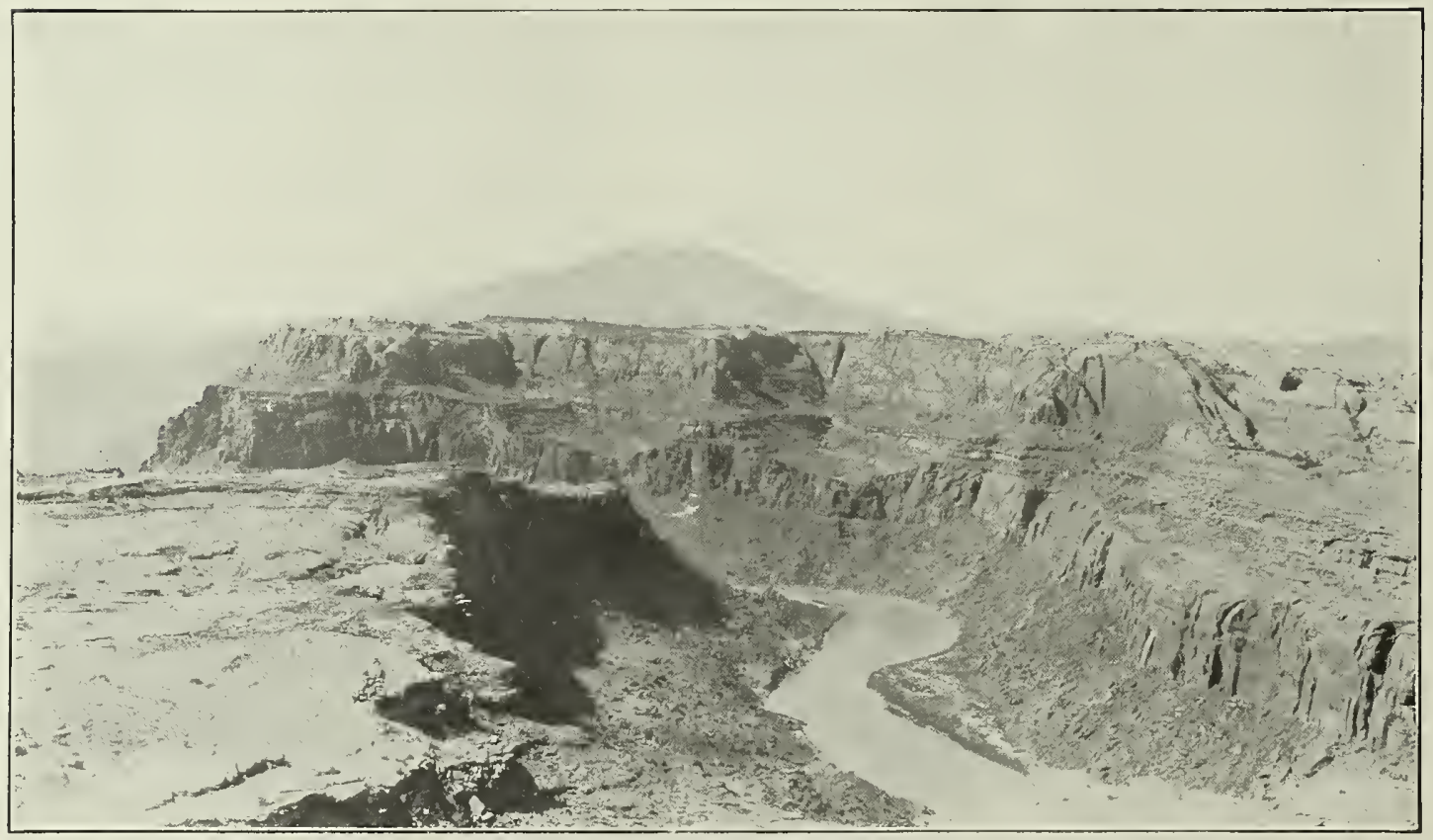

B. VIEW FROM POINT HALF A MILE SOUTH OF SPENCER CAMP, LOOKING SOUTH DOWN SAN JUAN GANYON TOWARD NAVAJO MOUNTAIN, UTAH.

Canyon tsas been cut in Navijo, Todilto (?), Wingate, aud Chinle formations. Photograph by Robert N. Allen. 


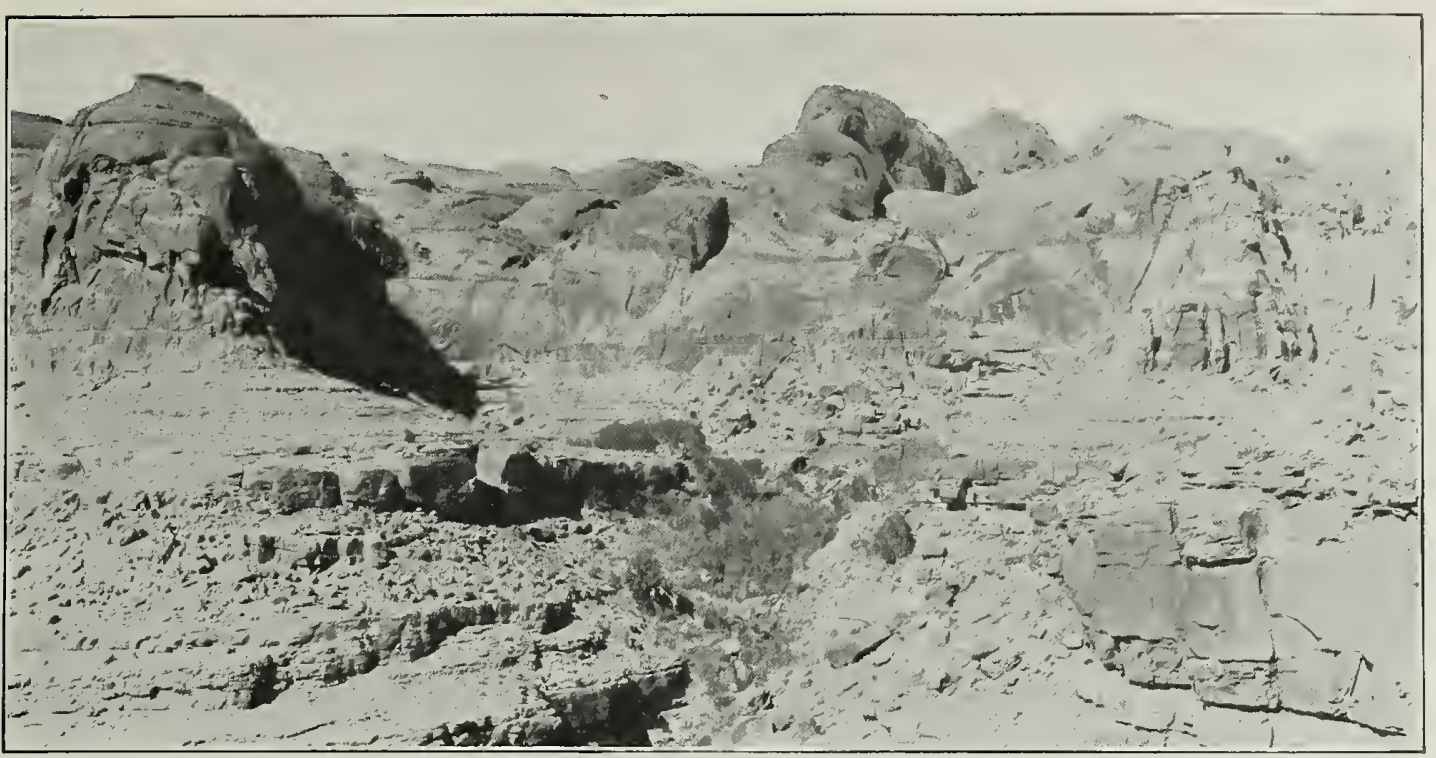

A. VIEW LOOKING NORTHEAST TOWARD WILSON MESA FROM POINT ON WILSON CREEK NEAR SAN JUAN CANYON, UTAII.

Showing bare domes and "mosques" of Navajo sandstone, Todilto (?) formation underlies platform in foreground. Photograph by Robert N. Allen.

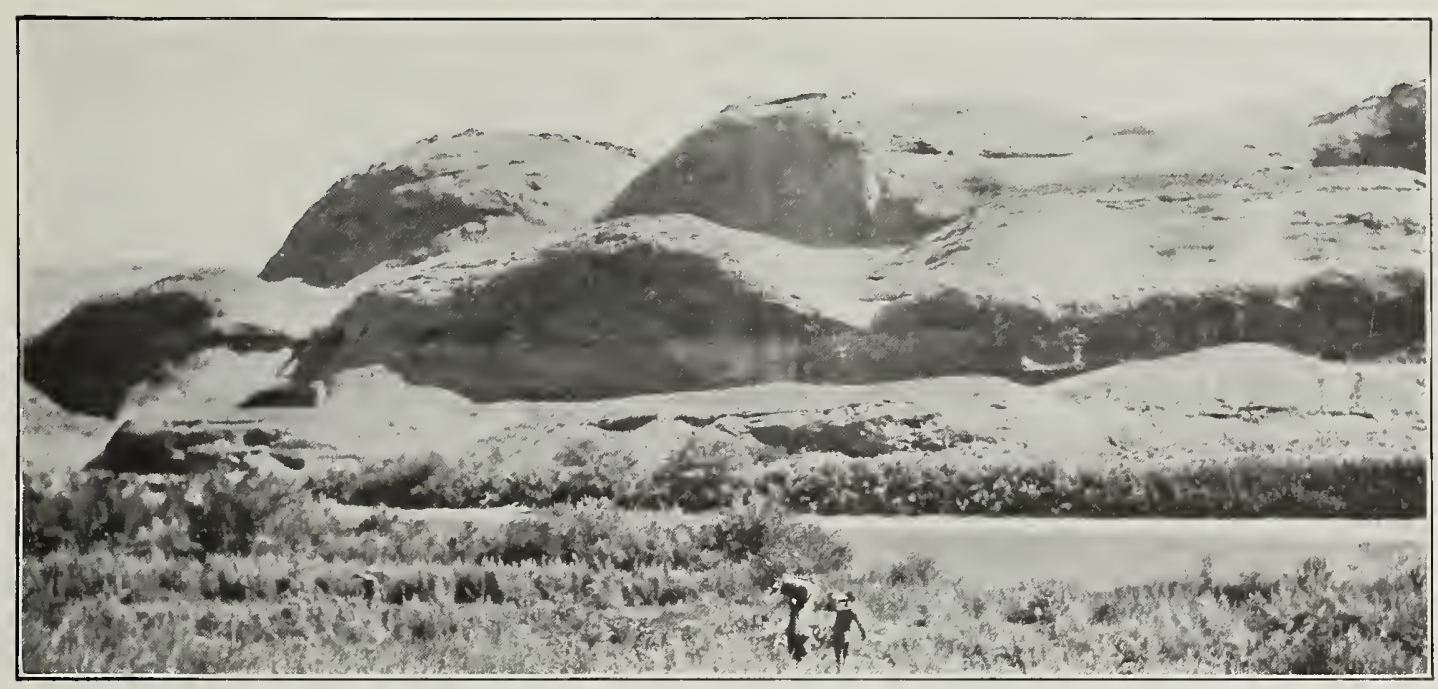

B. VIEW LOOKING ACROSS COLORADO RIVER OPPOSITE SMITIS FORK, UTAH. Showing colossal domes of Navajo sandstone. Photograph by Sidney Paige.

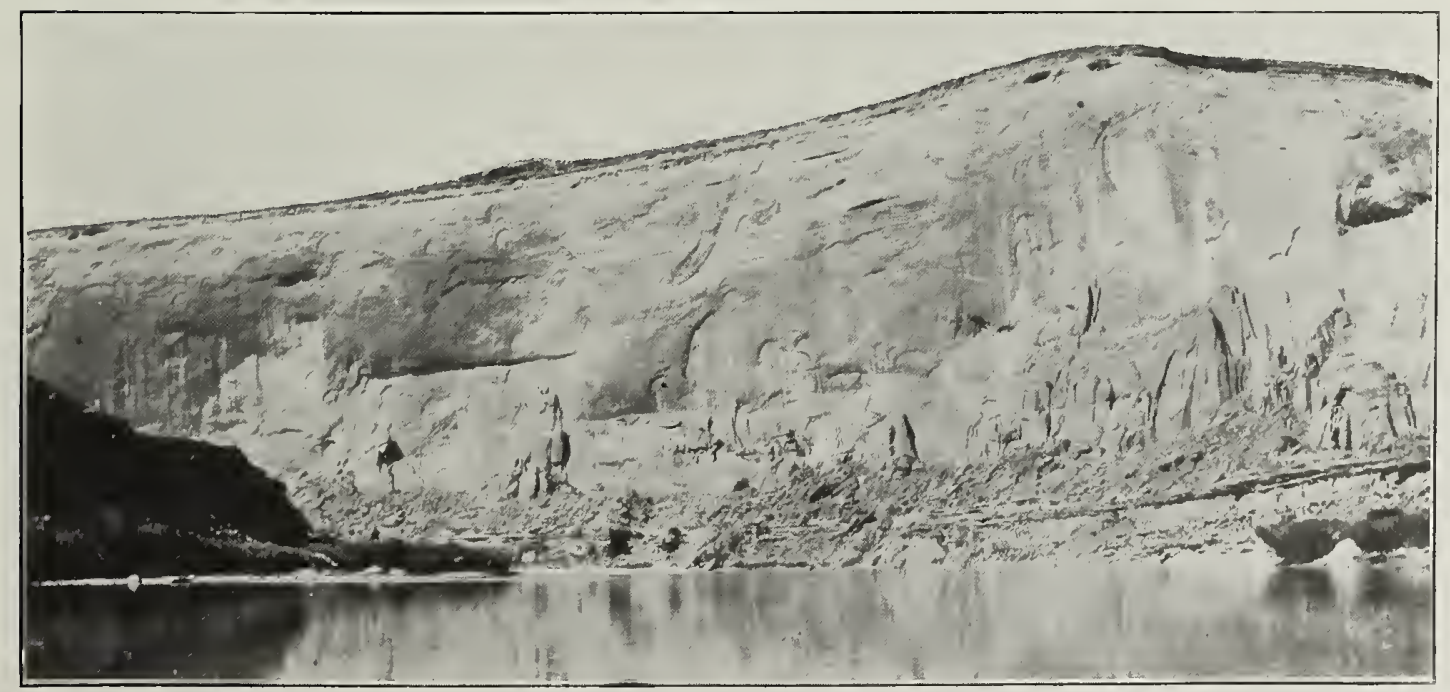

C. SHEER CLIFF OF NAVAJO SANDSTONE AT WARM SPRING CREEK ON COLORADO RIVER, UTAI,

Photograph by Sídney Paige. 


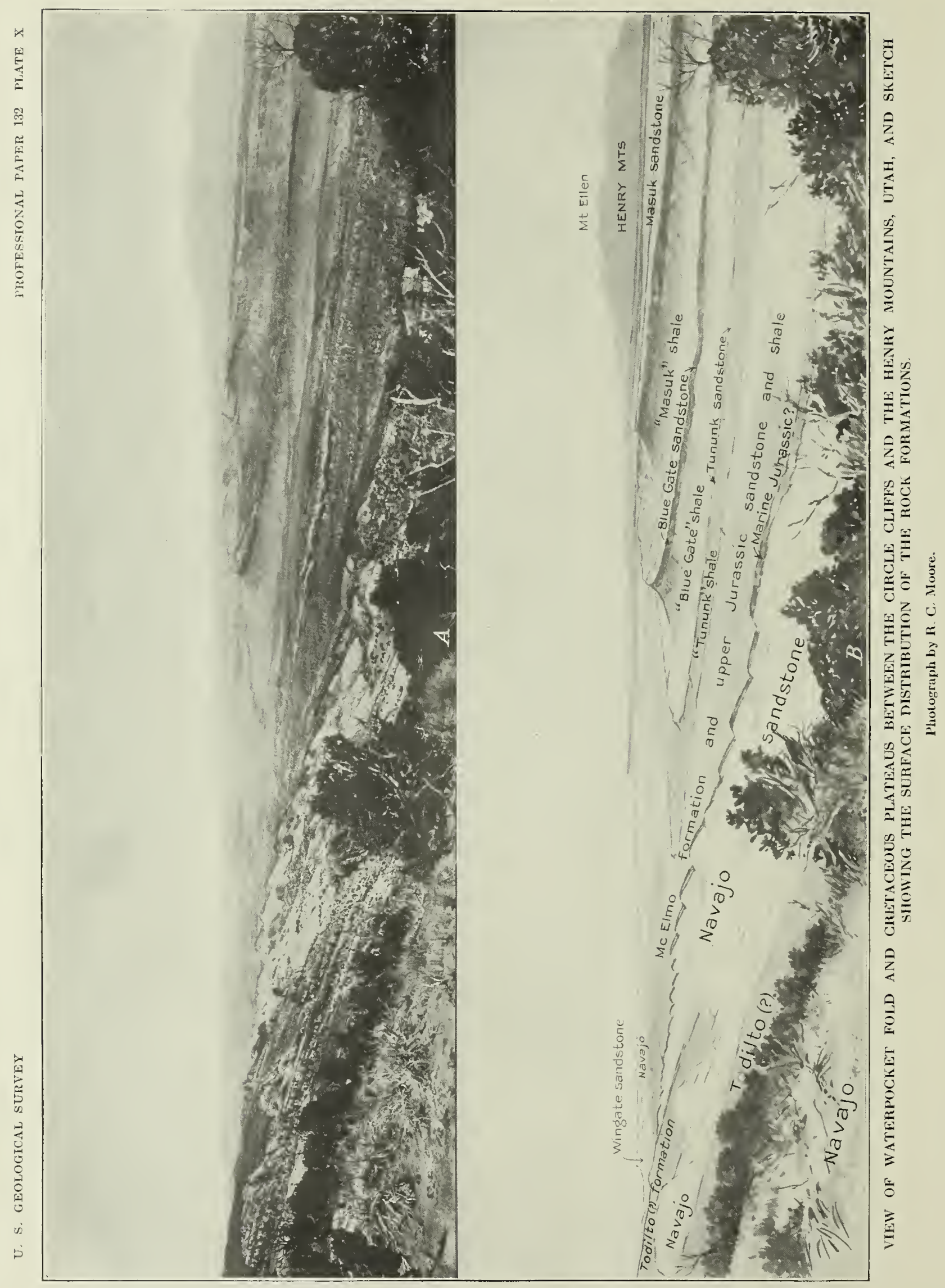


as well as the universal fineness and roundness of grain, suggest an eolian origin for this principal member. The only fossils reported from the formation are a few dinosaur tracks observed by Mr. Miser on surfaces of the lower lenticular beds at a locality several miles above the mouth of San Juan River.

The color of the sandstone on exposed surfaces gives the cliffs a striking appearance even in a "painted desert"; but the color is reddish brown rather than vermilion as suggested by the old formation name. On unweathered surfaces the rock is typically buff-colored, the darker shade ordinarily seen on cliffs resulting from weathering.

This sandstone forms the Vermilion Cliffs in western Kane County, Utah. Together with the overlying Todilto (?) formation it corresponds in age to Gilbert's Vermilion Cliff group in the Henry Mountains. ${ }^{32}$ But the massive sandstones of the Vermilion Cliffs near Lees Ferry, Ariz., and of the Echo Cliffs are made up not only of the Wingate sandstone but of the Navajo sandstone; the Todilto (?) formation has not been recognized and is apparently absent there.

Todilto (?) formation.-The character of deposits in the formation tentatively correlated with the Todilto varies considerably both vertically and horizontally; but the formation is sharply distinguished from the underlying and overlying sandstones by comparative thinness of beds and by undoubted evidence of deposition in water. Measured sections of the formation in the region under discussion range from 125 to 249 feet in thickness. Layers of flinty limestone and of calcareous shale are present in most localities, except perhaps to the north and west, but everywhere sandstone makes up the greater part of the thickness. The lower part is commonly very lenticular and contains considerable conglomerate with small sandstone pebbles. These beds, as well as others higher in the formation, were probably deposited by streams with rapid, shifting currents. The layers of shale and limestone are found for the most part in the middle and upper portions. The shale forms a zone of weakness that commonly causes the overlying Navajo sandstone to retreat behind the Wingate cliffs, leaving benches floored by the lower resistant sandstone of the

\footnotetext{
${ }^{32}$ Gilbert, G. K., Report on the geology of the Henry Mountains,
} pp. 5-7, U. S. Geog. and Geol. Survey Rocky Mtn. Region, 1880.
Todilto (?). (See Pls. VIII, $B$, and IX, A.) The limestone beds are lenticular and range from a few inches to 2 feet in thickness. The material is dense, hard, and cherty and is probably of fresh-water origin.

In some sections the transition from the massive Wingate to the thinner beds above appears to be gradual, but at many localities along the Colorado a distinct erosional unconformity separates the two formations, lenticular fluviatile beds filling valleys on the surface of the Wingate. In a cliff the lower sandstones of the Todilto (?) are readily distinguished from the light-colored Wingate by their dark-maroon or reddish-brown color. At higher horizons the Todilto (?) beds vary in color through shades of brown, tan, and lavender. The limestone layers are usually gray.

Navajo sandstone.--Many of the picturesque and grotesque erosion forms common in southern Utah and northern Arizona are carved in the Navajo sandstone of Gregory, which is essentially equivalent to Gilbert's "Gray Cliff group" and to Powell's White Cliffs sandstone. It is exposed over large areas along the Colorado and the San Juan, in the Waterpocket Fold and the Circle Cliffs, and farther west in south-central Utah and forms great tracts of almost impassable badlands, in which domes, "mosques," and "minarets" are common features. (See Pls. VI, B; VIII, and IX.) Caves, alcoves, and arches are conspicuous in cliffs of this sandstone, and it forms a number of natural bridges, notably the Rainbow and Owl bridges, near Navajo Mountain.

The thickness varies between wide limits, reaching a reported maximum of 1,800 feet in western Kane County, Utah, and a minimum of about 500 feet south of the Henry Mountains. Along the Colorado and the San Juan the thickness is commonly from 600 to 800 feet, but a few sections measure 1,000 feet. From the Waterpocket Fold westward the thickness is generally above 1,000 feet. There is also a marked change in color from east to west. From the Waterpocket Fold westward a large part of the formation is commonly gray or creamy white, whereas in the region south of the Henry Mountains, around Navajo Mountain, at Lees Ferry, and in Comb Ridge the sandstone is typically tan or buff.

This sandstone is frequently cited as a typical eolian deposit. Cross-bedding of the 


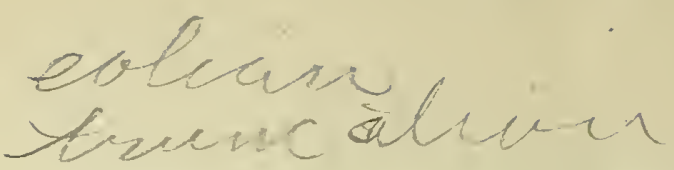

"tangential" type and on a very large scale characterizes the greater part of the formation, and the laminae of the cross-bedded structure show the abrupt and repeated truncation so commonly seen in "living" sand dunes. True bedding planes are present but not distinct, so that the entire formation stands in some cliffs with the appearance of a single massive layer. Beds of compact limestone from 2 to 5 feet thick lie at several horizons but chiefly in the upper half of the formation. These beds extend laterally from a few hundred feet to half a mile and probably represent deposition in shallow pans or basins. In view of the general high porosity of the sandstone, it would seem that these deposits required a high ground-water level, at least locally.

Gypsiferous shates and sandstones.-The series of beds here designated gypsiferous shales and sandstones is exposed at Bluff, in the Henry Mountains, and farther north, between Kaiparowits Plateau and Escalante River and along the Colorado below the mouth of the San Juan almost to Lees Ferry. (See Pl. X, A.) It is also found west of the Kaiparowits Plateau at several localities, notably in western Kane County, Utah, where it is apparently represented by about 100 feet of bluish-gray marl with considerable gypsum. In typical sections the beds consist of gypsiferous shale intercalated with layers of sandstone and some limestone, with an average total thickness of about 75 feet. In 1918 W. B. Emery ${ }^{33}$ studied these beds in the Green River Desert and reported the occurrence of marine Jurassic fossils in some of the limestone layers. This fossiliferous series had been noted previously by Gilbert ${ }^{34}$ and by Lupton. ${ }^{35}$ In some sections there are indications of an unconformity between these beds and the underlying Navajo sandstone.

The beds deserve a formation name, but it appears best to postpone assigning a definite name until the Todilto problem, discussed above, has been finally solved by further field work.

Varicolored sandstones and shales.-The thick series of beds here termed varicolored sandstones and shales includes the greater portion of the rocks in Gilbert's "Flaming Gorge

33 Op. cit., pp. 568-569.

31 Gilbert, G. K., Geology of the Henry Mountains, p. 6, 1880

${ }^{25}$ Lupton, C. T., U. S. Geol. Survey Bull. 628, p. 24, 1916. group." These beds reach a maximum thickness of approximately 1,430 feet in the Waterpocket Fold. (See Pl. X, A.) Along Colorado River between the mouth of the San Juan and the Crossing of the Fathers the series appears to have a thickness as great as 500 feet, and near Bluff it is from 170 to 270 feet thick. Complete and partial sections are exposed at many localities, south and west of the Henry Mountains and northeast of the Kaiparowits Plateau. The series contains a massive crossbedded sandstone member, tan, red, and gray, which has some resemblance to the typical Navajo sandstone. Other parts of the section consist of thin-bedded sandstone, much of it shaly. East of the Waterpocket Fold the predominant colors are red and tan, but in western Kane County, where the stratigraphic position of the series is occupied chiefly by sandy shale, many of the beds are gray and bluish gray.

Emery considers that this series of beds, as well as those at the horizon of the marine Jurassic, corresponds to the La Plata sandstone of Cross. Gregory limits the La Plata group to his Wingate, Todilto, and Navajo formations.

\section{MCELMO FORMATION (CRETACEOUS?).}

The McElmo formation, of Cretaceous (?) age, is exposed near Bluff, where it consists of gray, red, and green shale and thin beds of sandstone with two heavy conglomeratic layers, making an incomplete section several hundred feet thick. At places these conglomerates contain carnotite deposits. Along the Colorado below the San Juan partial sections of the formation are made up chiefly of a massive cliffmaking greenish-gray sandstone, in part conglomeratic. In western Kane County the McElmo appears to be represented by a coarse conglomerate of undetermined thickness.

\section{CRETACEOUS SYSTEM.}

Rocks of known Cretaceous age, all probably belonging to the Upper Cretaceous series, are represented in southern Utah by exposures in the vicinity of the Henry Mountains, along the southern border of the High Plateaus in western Garfield and Kane counties, and in a southeastward projection, of which Kaiparowits Plateau is the chief part, extending into eastern Kane County. (See Pl. X, $A$ and $B$.) 
The total thickness of the Cretaceous section in this region is about 3,500 feet. The rocks consist of alternating divisions of bluish-drab shale and yellowish-brown sandstone, the former appearing in slopes and badlands, the latter in more or less prominent escarpments and hogback ridges. They are divisible into seven distinct units, the basal one of which is doubtfully correlated with the Dakota sandstone. To the rocks above this basal sandstone Gilbert applied the following local names, in ascending order: Tununk shale, Tununk sandstone, Blue Gate shale, Blue Gate sandstone, Masuk shale, and Masuk sandstone. These names were derived from geographic features in the Henry Mountains. As duplication of names is contrary to the practice of the United States Geological Survey, only Gilbert's names for the sandstones have been adopted, and in this report his names for the shales will be used in quotation marks, because of the doubt regarding the relations of this whole succession of sandstone and shale to named units to the north and east. In the present state of knowledge Mr. Moore tentatively correlates the "Tununk shale," Tununk sandstone, and "Blue Gate shale" with the Mancos shale of southwestern Colorado and east-central Utah. The Blue Gate sandstone he tentatively correlates with the Mesaverde formation, the "Masuk shale" with the Lewis shale, and the Masuk sandstone with the socalled "Laramie" sandstone of southwestern Colorado. Some geologists, however, believe that the whole succession corresponds to the Mancos shale.

Dakota (?) sandstone.-As in most of the Cretaceous sections of the Rocky Mountain and Plateau region, there is present in southern Utah a basal sandstone and conglomerate which appears to be homotaxially equivalent to the Dakota sandstone. This sandstone attains a thickness of 100 feet in the escarpment of Kaiparowits Plateau, but in the Henry Mountains district it is much thinner and in places is absent. It evidently overlies the beds beneath it unconformably, for the upper surface of the McElmo is somewhat uneven, the thickness of the upper division of the McElmo is variable, and at one place a slight fold in the McElmo strata was found to have been truncated before the deposition of the sandstone.
To these evidences may be added the conglomeratic character of the formation. The color of the Dakota (?) sandstone is yellowish brown to white. The bedding is irregular. Locally thin beds of lignite are present.

"Tununk shale."-The formation above the Dakota (?) sandstone consists of bluish-drab argillaceous and in part sandy shale, called "Tununk shale" by Gilbert. The shale is 900 to 1,000 feet thick in exposures east of the Waterpocket Fold. It is very sandy and grades at the base into extremely fossiliferous brown sandstone. The shale is also fossiliferous, containing especially large numbers of Gryphaea newberryi.

Tununk sandstone.-The sandstone overlying the shale just described was called Tununk sandstone by Gilbert. It has a maximum observed thickness of about 100 feet. It is well developed in the vicinity of the Henry Mountains and appears to be present in the Kaiparowits Plateau but was not found southwest of Table Cliff Plateau in western Garfield County. It is light yellowish brown, is irregularly bedded, and locally contains some lignite.

"Blue Gate shate."-Overlying the Tununk sandstone is a shale formation 1,100 to 1,200 feet thick, which resembles the "Tununk shale" in texture and color but lacks the numerous fossils that are characteristic of the "Tununk." To this shale Gilbert applied the name "Blue Gate shale."

Blue Gate sandstone.-A prominent creamyyellow to light-brown massive and irregularly bedded sandstone succeeds conformably the shale just described. Its thickness in the Henry Mountains, where it was named the Blue Gate sandstone by Gilbert, ${ }^{36}$ is 250 to 500 feet, but in the Kaiparowits Plateau and west of Escalante the thickness of this formation is at least 1,000 feet. The sandstone contains lignite, which locally is of very good grade and reaches a thickness of 4 feet west of Mount Ellen. No fossils were obtained from this sandstone, but Lee ${ }^{37}$ has suggested that it is comparable with the Mesaverde. It is extremely improbable that this sandstone could represent the Ferron sandstone of Castle

¿6 Gilbert, G. K., op. cit., p. 4.

37 Lee, W. T., Relation of the Cretaceous formations to the Rocky Mountains in Colorado and New Mexico: U.S. Geol. Survey Prof. Paper 95, p. 50,1915 
Valley, as suggested by Lupton. ${ }^{38}$ The Ferron occurs about 600 feet above the base of the Mancos as there identified and is overlain by 3,000 feet of Mancos shale, whereas this sandstone is 2,200 feet above the base of the Mancos and, as seen in the Henry Mountains, is succeeded by only a few hundred feet of shale. The Cretaceous section of southern Utah appears to be intermediate in character between those of southwestern Colorado, northwestern New Mexico, and northern Arizona and those of central and northern Utah.

"Masuk shale."-Above the Blue Gate sandstone is a light-drab, very sandy shale, which in the Henry Mountains area has a thickness of 500 to 700 feet and to which Gilbert applied the name "Masuk shale." Below Table Cliff Plateau, in western Garfield County, the thickness of this shale is undetermined but is probably more than 1,000 feet. The upper part of the shale contains thin beds and lenses of brown sandstone and appears to grade without break in to the overlying formation, the Masuk sandstone.

Masuk sandstone.-The uppermost Cretaceous formation in the region is a massive yellowish-gray sandstone, which east of the Circle Cliffs appears in a prominent table-land bounded by high, sheer cliffs. Its thickness is about 300 feet according to measurements made at its west margin, but Gilbert ${ }^{39}$ reports a thickness of 500 feet.

\section{TERTLARY SYSTEM.}

In the High Plateaus are found exposures of the youngest stratified rocks of the region, comprising pink, lavender, white, and varicolored limestones, sandstones, and shales of Eocene age. These rocks, which in Garfield and Kane counties have been "referred to the Wasatch formation, appear in vertical cliffs and in the fantastically carved, brilliantly tinted walls of canyons that head along the margins of the plateaus. The thickness of the Tertiary sequence in this region is about 2,000 feet. Much of it, especially toward the north, is buried beneath a great accumulation of extrusive igneous rocks.

The Tertiary beds rest with very great unconformity on the Mesozoic rocks, the unconformity being angular as well as erosional. The base of the Tertiary is found in contact

${ }_{38}$ Lupton, C. T., Geology and coal resources of the Castle Valley, Utah: U. S. Geol. Survey Bull. 628, p. 32, 1916.

${ }^{39}$ Gilbert, G. K., op. cit., p. 4. successively with all the formations from the highest Cretaceous to the Navajo sandstone, and much of the Navajo was in places removed before Eocene sedimentation. It therefore appears that an important deformative movement, in which such structural features as the Waterpocket Fold, the Circle Cliffs dome, and the gentle flexures south of Table Cliff Plateau were formed, followed Cretaceous deposition, and that before the deposition of the Tertiary strata began this deformed rock series had been planed off by erosion to a nearly level surface, a denudation involving the removal in places of rock strata some thousands of feet in thickness.

\section{LOCAI SECTIONS.}

General section of rocks near Lees Ferry, Ariz.

$$
\text { [Measured by Kirk Bryan.] }
$$
Navajo and Wingate sandstones: Massive tanUnconformity.

Moenkopi formation: Red sandy shale and Unconformity.

Coconino sandstone: Gray cross-bedded mas-

Hermit (?) shale: Red shale

Unconformity (?) (not ob-
Brown thin-bedded sandstone and shale, which are probably the equivalent of the beds of marine Jurassic farther north..... gentially cross-beddied red to buff sandstone. No parting visible at the center, but upper half has lenses of dense gray limestone 6 inches to 3 feet thick at intervals, and near the top nodules of limonite the size of peas are common. In the Vermilion Cliffs the upper half is distinctly lighter in color. The Todilto (?) formation is apparently absent................... Chinle formation: Blue, green, and red shale; white, gray, purple, and red sandstone; and cherty limestone. Upper part consists of heavy-bedded sandstone and red shale; lower part contains fossil wood.....

Shinarump conglomerate: Gray conglomerate with lenses of sandstone and shale; much fossil wood ......................... thin-bedded sandstone with seams of gypsum. In places has beds of red and gray sandstone 2 to 6 feet thick, and in one locality 12 feet of gypsiferous limestone at the top. Base, generally, 1 to 10 feet of chert conglomerate.......................

Kaibab limestone: Yellow limestone with numerous more or less rounded nodules of chert............................ sive sandstone.................... Unconformity (?). and sandstone .............. served).

(?) (not ob- (observed)..

$500 \pm$

Feet.

$1,000 \pm$

$0-40$

$500 \pm$

Supai formation: Red shale with beds of blue limestone. 
Section about 3 miles southeast of Piute Farms on San Juan River.

[Measured by H. D. Miser.]

Wingate sandstone:

Massive cross-bedded tan sandstone forming sheer cliff; cut by numerous vertical joints; face of cliff is stained dark brown.......... Coarse brown sandstone with pebbles of shale and sandstone up to 2 inches in diameter....

Chinle formation: Green and pink marly clay with beds of mottled pink and gray compact limestone as much as 4 feet thick in upper part. Some of the limestone is conglomerate. Pebbles in conglomerate are limestone. Pink and gray flint on slope may have been derived from weathering of limestone. Some parts of clay contain irregular concretions of calcareous earthy material... Shinarump conglomerate: Massive gray sandstone.. Moenkopi formation:

Chocolate-colored shale with some green shale in upper half; light chocolate-colored shale with some thick beds of brown fine-grained sandstone in lower half. ................

Brick-red sandy shale and earthy sandstone in beds of uniform thickness. The De Chelly (?) sandstone is absent at this place but wedges in farther south near the top of this part of the formation.........................

Moenkopi or Coconino: "Transition beds", like those described in section at Zahns Camp.

Coconino sandstone.

Section at Zahns Camp on San Juan River.

[Measured by H. D. Miser.]

Chinle formation: Variegated marly shale.

Shinarump conglomerate: Massive gray pebbly sandstone; forms cliff. ....................

Moenkopi formation:

Chocolate-brown sandy shale with a smaller amount of brown shaly and platy sandstone; forms steep slope......................

Brick-red sandy shale and earthy sandstone in even-bedded layers.....................

Cream-colored cross-bedded massive sandstone; De Chelly (?) sandstone lentil.............

Brick-red sandy shale and a smaller amount of red earthy sandstone in even-bedded layers............................

Total thickness of Moenkopi formation. ... 920

Moenkopi or Coconino ("transition beds"):

Heavy gray sandstone. . . . . . . . . . . . . .

Brown sandy shale and brown shaly sandstone. A bed of gray limestone 1 foot or more thick

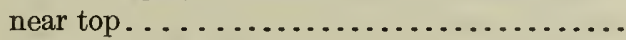

Massive gray sandstone ..................

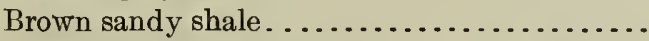

Massive gray sandstone...................

Brown sandy shale and brown earthy sandstone. Contains one or two thin beds of gray limestone.............................

Total thickness of "transition beds"......
Coconino sandstone: Massive cross-bedded cream- Feet. colored sandstone. Two beds of brown sandy shale aggregating 3 feet near the top. Exposure of sandstone extends down to San Juan River......

Section on San Juan River north of Spencer Camp.

4 Navajo sandstone: Cream-colored to yellow massive [Measured by H. D. Miser.)

cross-bedded sandstone................. $200+$

Todilto (?) formation:

Brown fine-grained shaly sandstone with lavender cast. . . . . . . . . . . . . . . . . . . . 170

Lenses of conglomerate as much as several feet thick; conglomerate composed of sandstone pebbles in sandy matrix...............

Lavender, brown, and buff fine-grained sandstone in comparatively thin layers........ 50

Total thickness of Todilto (?) formation. 220 Wingate sandstone: Buff fine-grained cross-bedded sandstone; no conglomerate at basé. . . . . . . . . . 330

340 Chinle formation: Variegated marly shale; concealed almost everywhere by landslides. Formation extends to river, and base is not exposed .... 510

Section on north side of San Juan River just above its junction with the Colorado.

Navajo sandstone: [Measured by H. D. Miser.]

Gray thin-bedded very fine grained limestone; forms flat top of small mesa............. $4 \frac{1}{2}$

Buff massive cross-bedded sandstone........ 310

Todilto (?) formation: Dark and light brown sandstone in comparatively thin beds............ 200

Wingate sandstone: Buff sandstone to water's edge of San Juan River...................... $10+$

Section on Colorado River near the mouth of Fremont River.

[Measured by C. R. Longwell. The canyons of Colorado and Fremont rivers are cut in the Coconino sandstone. Above the canyons there is a wide stripped bench on the Coconino, with scattered buttes of the Moenkopi formation.]

Moenkopi formation:

Feet.

Conglomerate at base of upper member of formation. Contains angular pebbles of chert, with maximum length of 2 inches, also a few fragments of silicified wood. Firmly cemented by calcium carbonate............ Unconformity.

Gray sandstone, medium to coarse, strongly cross-bedded throughout. Conspicuous by contrast with red sandstone below. De Chelly (?) lentil......................

Regular beds (a few with cross laminae) of red to maroon sandstone, averaging several feet in thickness, of fine, uniform grain. A few shaly layers, forming narrow benches in cliff.

Heavy bed of cross-bedded pink to tan sandstone; persistent, good horizon marker; fine uniform grain...........................

Heavy bed of reddish-brown sandstone, grading into gray at the base.................

\author{
00
}

政


Moenkopi formation-Continued.

Fine-grained maroon and red sandstone and sandy shale in regular beds from 6 to 30 inches thick; form steep interrupted slope.........

Red sandy shale, with some layers of crossbedded fine-grained sandstone; forms slope; muscovite abundant. ..................

Massive white to gray sandstone, with medium grain.............................

Gritty shale and fine-grained sandstone, red to light brown......................

Incomplete thickness of Moenkopi forma-

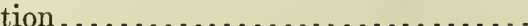

Unconformity.

Coconino sandstone: Gray and tan sandstone, of fine to medium grain, in massive beds and with crossbedding on large scale. Forms walls of Narrow Canyon and Dirty Devil Canyon. Base not exposed.

Section on Colorado River near mouth of Crescent Creek ("North Wash").

[Measured by C. R. Longwell.]

Wingate sandstone forms a sheer cliff at least 300 feet high, at top of the steep slope on which the

Chinle formation is exposed................. $300+$

Chinle formation:

Regular beds of pink sandstone, 6 inches to 2 feet thick.......................... 12

Coarse sandstone, pink to tan, cross-bedded.... 25

Gritty shale and fine-grained sandstone, in thin layers. . . . . . . . . . . . . . . . . . . . . 10

Gray calcareous sandstone................. 1

Pink sandstone in thin beds............... 27

Massive layer of gray to buff sandstone........ 6

Calcareous shale in massive layers, containing more or less grit, with a few intercalated thin layers of fine-grained sandstone...... 155

Heavy bed of dense gray limestone, with chert lenses and nodules......................

Pink calcareous shale.................. 24

Alternating layers of gray limestone and pinkish shale. Limestone layers average 2 feet in thickness and are dense, with abundance of chert.............................

Gray, lavender, and yellow shale, banded, with a few thin sandy layers.............. 102

Total thickness of Chinle formation..... 393 Shinarump conglomerate: Massive coarse-grained, cross-bedded sandstone, with lenses of conglomerate; contains abundance of silicified wood......

Unconformity.

Moenkopi formation:

Lavender, pink, and greenish shale, with a few sandstone layers; green layers prominent near top............................

Gray and yellow sandy shaie and fine-grained

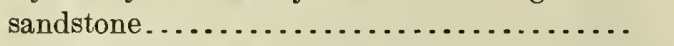

Bright-red clay shale.................. 22

Gray, lavender, and yellow shale, with a few bands of dense gray limestone..............
Feet. Moenkopi formation-Continued.

. Red and pink sandy shale and fine-grained sandstone...........................

Fine-grained cross-bedded red to pink sandstone.

Alternating layers of gray sandștone and red shale; shale papery, sandstone ripple marked.

Alternating layers of red and brown sandstone and sandy shale; sandstone layers have current and ripple marks, also a few rain prints; partings of brown paper shale..............

Single bed of massive cross-bedded light-brown sandstone.

Alternating layers of red and brown sandstone and sandy shale; sandstone layers have current and ripple marks, also a few rain prints.

Alternating thin beds of gray sandstone, with very thin partings of brown shale..........

Light-brown conglomeratic sandstone.........

Alternating thin beds of gray sandstone, with very thin partings of brown shale..........

Light-brown conglomeratic sandstone........

Alternating thin beds of gray sandstone, with very thin partings of brown shale..........

Light-brown conglomeratic sandstone........

Alternating thin beds of gray sandstone, with very thin partings of brown shale..........

Massive gray cross-bedded sandstone. . . . . . . .

Alternating thin beds of sandstone and shale, yellow, red, brown, and lavender..........

Firmly cemented conglomerate with angular pebbles of chert and hard sandstone; fragments of lustrous coal and of silicified wood also occur as pebbles. .................

Total thickness of upper member of Moenkopi formation ................. Unconformity.

Massive gray sandstone, with marked crossbedding, loosely cemented with calcium carbonate. De Chelly (?) sandstone lentil..

Typical red and maroon beds of lower member.

Section on Colorado River below mouth of Crescent Creek. [Measured by C. R. Longwell.]

Navajo sandstone: Tan and buff sandstone, crossbedded on large scale. The sandstone of this locality is an isolated remnant capping a high point..................................

Todilto (?) formation:

Alternating regular beds of calcareous sandstone and gritty shale, with a few layers of limestone conglomerate. Two of the sandstone layers are cross-bedded and tan. Other beds are pink, gray, and lavender. Form long slope..........................

Thin layers of red and maroon sandstone, crossbedded.

Light-brown and gray cross-bedded sandstone; friable, forming slope; contains hard, concretionary nodules.....................

Total thickness of Todilto (?) formation.. 159 
Unconformity (?).

Wingate sandstone:

Tan and light-brown cross-bedded sandstone, forming cliff. ........................

Conglomerate, with pebbles and boulders of sandstone as much as 2 feet in diameter, also pebbles of red clay; calcareous cement......

Massive cross-bedded sandstone, forming almost unbroken cliff. Tan on fresh surfaces, reddish brown on weathered face.

Total thickness of Wingate sandstone... Chinle formation: Forms a long slope below the cliff of the Wingate sandstone.

Section on Colorado River near mouth of Trachyte Creek.

[Measured by C. R. Longwell.]

Shinarump conglomerate: Coarse-grained gray conglomeratic sandstone, with abundance of silicified wood. Forms low cliff, with shelf above........

Unconformity.

Moenkopi formation:

Alternating layers of gray sandstone and greenish shale............................ Lavender, gray, and pink calcareous shale.... Fine-grained brown sandstone............. Gray "marl," sandy near base. . . . . . . . . . . Gray cross-bedded sandstone............... Greenish-gray and pink shale, paper-thin..... Bright-red clay shale..................... Yellow, lavender, pink, and gray "marly" shale, in thick beds...................

Alternating chocolate-colored shale and gray to brown sandstone, in thin layers. Ripple marks abundant. ....................

Massive brown sandstone with strong current marks............................

Alternating chocolate-colored shale and graý to brown sandstone.......................

Massive sandstone.......................

Chocolate-colored sandy shale. .............

Massive cross-bedded sandstone..............

Gray sandstone and chocolate-colored shale, in alternating thin layers...................

Massive gray to brown cross-bedded sandstone..

Alternating chocolate-colored shale and gray to brown sandstone, with strong ripple marks. .

Light-brown cross-bedded sandstone..........

Chocolate-colored sandy shale. .............

Thick layers of sandstone, with thin partings of chocolate-colored shale.................

Alternating gray sandstone and chocolatecolored shale........................

Heavy layers of cross-bedded current-marked sandstone, with thin shale partings; sandstone gray to brown, shale dark chocolatecolored.

Brown fine-grained sandstone, with thin lamination..............................

Heavy layers of pink cross-bedded sandstone, with shale partings.....................

Alternating gray sandstone and brown shale; abundant ripple and current marks.........
Feet. Moenkopi formation-Continued.

Feet.

Fine-grained sandstone with shaly lamination.. 9

Firmly cemented conglomerate containing angular pebbles of chert and hard sandstone. .

Total thickness of upper member of

Moenkopi formation.................

Unconformity.

De Chelly (?) sandstone lentil (gray to pink cross-bedded sandstone).................

Typical red beds of the lower member.

Section on north side of Twomile Canyon, directly east of Mount Holmes, in the Henry Mountains.

[Measured by C. R. Longwell.]

Navajo sandstone: Massive tan sandstone, capping a rounded hill......................... $\quad 250$

Todilto (?) formation:

Massive fine-grained cross-bedded lavender and gray sandstone.....................

Purple and gray shale; forms slope..........

Massive cross-bedded brown sandstone, medium to coarse.........................

Red and brown sandy calcareous shale with thin layers of dense gray limestone; forms slope.............................

Brown and gray heavy-bedded sandstone with calcareous cement.....................

Pink sandy shale; forms slope.............

Gray sandstone and pink sandy shale in alternating beds.........................

Reddish-brown and gray medium to fine grained sandstone in heavy layers, some with cross-bedding. Calcareous cement. Layers of unequal resistance, forming steep slope. All beds lenticular; a few lenses conglomeratic........................

\section{Unconformity.}

Total thickness of Todilto (?) formation.

Wingate sandstone: Tan to reddish-brown sandstone, chiefly in unbroken cliff. Large-scale cross-bedding ..............................

8 Unconformity (?).

Chinle formation:

Alternating layers of hard fine-grained sandstone and pink sandy shale.............

Pink shale, with a few layers of gray sandstone. Gray conglomeratic sandstone, with small pebbles of chert and hard sandstone.......

Heavy bed of fine-grained pink sandstone, loosely cemented .....................

Varicolored calcareous shale, with a few sandstone layers.........................

Cross-bedded gray sandstone, conglomeratic at base; contains silicified logs..............

Pink and yellow calcareous shale, sandy near top..............................

Hard gray limestone, containing chert nodules.

Lenticular layers of gray sandstone with partings of shale..........................

Pink and yellow gritty shale..............
Feet 
Chinle formation-Continued.

Gray and lavender "marl l" beds, jointed..... Cross-bedded gray and lavender sandstone... Massive fine-grained sandstone, rich with calcium carbonate and containing cherty nodules.............................

Brick-red gritty shale, with layers of gray sandstone.........................

Pink and gray calcareous shale or "marl," appearing massive ......................

Gray and purplish sandy shale in thin beds...

Total thickness of Chinle formation ....

Shinarump conglomerate: Coarse conglomeratic massive and cross-bedded sandstone with lenses of conglomerate; abundance of silicified logs; plain impressions of plants on bedding surfaces. Forms vertical cliff.

Unconformity.

Moenkopi formation: Greenish shale immediately below unconformity. Forms slope.

Section of Chinle formation at north end of prominent Wingate-capped outlier west of South Fork of Silver Falls Creek, in the Circle Cliffs.

[Measured by R. C. Moore.]

Wingate sandstone: Reddish-brown fine-grained cross-bedded, very massive sandstone, forming single vertical wall; prominently jointed; basal few feet horizontally bedded in thin layers, with ripple marks measuring about 6 inches from crest to crest; thickness estimated................

Chinle formation:

Soft limestone, lavender mottled with light greenish blue, weathering in very irregular fragments; partly covered with débris; upper part oxidized and stained to dark purple beneath Wingate sandstone and along joints.

Light-bluish conglomerate, mostly rather finegrained; pebbles consist almost entirely of limestone like the associated limestones of the Chinle formation, but there are some flint, quartz, and ironstone pebbles as much as $1 \frac{1}{2}$ inches in diameter; upper part grades into very coarse limestone grit, with lines and lenses of fine conglomerate; very massive; crops out in prominent bench........

Soft shaly limestone, light greenish blue and lavender, mottled; contains locally harder limestone in beds 6 to 10 inches thick which project; this division weathers in a slope...

Very hard dense fine-grained limestone, light bluish in lower part with mottling of lavender, massive and uniform; locally contains calcite crystals; except for lower part, which is somewhat softer, this bed forms prominent cliff, which in places overhangs................

Light-blue hard calcareous shale; forms landslide slope.........................

Argillaceous limestone, impure, mottled light greenish blue and lavender; weathers in small angular fragments but forms at outcrop a massive vertical ledge; grades upward and downward into hard calcareous shale.
Feet. Chinle formation-Continued.

34 Light-blue hard calcareous shale; forms slope..

Hard dense nodular limestone, mottled light greenish blue and lavender; weathers in small irregular-shaped fragments; grades imperceptibly into shale above and below; forms bench

Hard calcareous light-blue shale, forming slope. Light-bluish shaly soft, very micaceous sandstone, grading into sandy shale.

Light-bluish to brown limestone conglomerate, containing pebbles of limestone and chert 3 inches or less in diameter; grades into coarse limy sandstone.......................

Yellowish-brown hard sandy shale grading to ash-gray and lavender shale...............

Grayish-blue to lavender calcareous, highly micaceous sandstone, grading upward into soft massive cross-bedded sandstone; lower part weathers in thin platy fragments........

Purple shale, grading upward into yellow and blue shale; sandy, especially in lower part; contains abundant mica; weathers in rounded slopes.............................

Brownish-gray thinly laminated to platy sandstone, weathering dark brown; lower part locally conglomerate, containing pebbles of ironstone and jasper as much as 1 inch in diameter...........................

Sandy shale; upper part weathers to shades of lavender and purple; lower part darker; the proportion of sand increases toward the top; contains satin spar, crystals of gypsum, and mammillary concretions of ironstone with crystalline calcite; weathers in rounded slopes.............................

Brown thin-bedded flaggy sandstone, grading laterally to burnt sienna slaggy ironstone, containing nodules of limonite; this bed forms a bench that weathers irregularly in crumbly fragments....................

Hard calcareous sandy shale, light greenish blue predominant in variegated coloring; weathers in rounded badland slopes........

Total thickness of Chinle formation...... Shinarump conglomerate: Grayish-brown irregularly bedded massive sandstone, showing thin cross lamination; some of the weathered surfaces are dark brown or black on account of a surface deposit of iron oxide; contains bluish sandy shale in middle part . ........................ Moenkopi formation.

Section of Kaibab limestone west of The Peaks, in the Circle Cliffs.

[Measured by R. C. Moore.]

Moenkopi formation.

Kaibab limestone:

Yellow dolomitic limestone in massive evenly bedded ledges; weathers in large angular blocks pitted by solution; part contains numerous dendrites of manganese oxide and concretions of a mineral resembling wad; contains fossils; forms resistant cap of promi-

Feet. nent bench. 
Kiabab limestone--Continued.

Light-yellow soft dolomitic massive limestone, filled with angular fragments of chert; weathers in smooth slope; exposed.........

Soft light creamy-yellow thin to medium bedded limestone; weathers in slope; partly concealed.

White very sandy limestone, rounded sand grains scattered rather evenly; more lime than sand; weathers in thick ledges........

White medium to coarse grained massive sandstone; rounded quartz grains in a lime matrix..............................

White very sandy limestone, rounded sand grains scattered rather evenly; more lime than sand; weathers in thick ledges; forms bench.

Total thickness of Kaibab limestone....

Coconino (?) sandstone: White medium to coarse grained moderately soft massive sandstone; rounded quartz grains in a lime matrix; breaks into irregular blocks on weathering; exposed.....

Section of lower beds in front of Kaiparowits Plateau, south of Tenmile Spring, about 15 miles southeast of Escalante, in middle part of sec. 4, T. 37 S., R. $4 \mathrm{E}$.

[Measured by R. C. Moore.]

"Tununk shale": Bluish sandy shale, grading downward into soft fossiliferous sandstone...... $400+$

Dakota (?) sandstone: Conglomeratic buff to almost white coarse to medium grained sandstone, containing lenses of conglomerate with pebbles as much as 3 inches in diameter; irregularly crossbedded; forms cliff and prominent bench.

McElmo formation:

Red and light-brown sandy shale, interbedded with sandstone of similar color; forms slope partly concealed.

Light-brown and yellow fine-grained sandstone, cross-bedded in part; occurs in massive layers and forms bench..................... 70

Total thickness of McElmo formation. . . 125

"Varicolored shales and sandstones":

Red and gray shale and sandstone, interbedded; mostly covered.......................... 12

Red, gray, and drab sandstone and shale, in thin alternating beds; considerable variation in color and texture....................

Yellow and buff soft, very massive sandstone; weathers in smooth round slopes, locally with caves and shallow depressions at outcrop.... $300+$

Partial thickness of "varicolored shales and sandstones"
Section on Halls Creek about 8 miles above its mouth.

[Measured by R. C. Moore.]

15

\section{Nava}

Navajo sandstone: White medium-grained very massive cross-bedded sanstone; forms prominent ridge.

Section across Waterpocket Fold near southwest corner of $T$. 32 S., R. 8 E., at Bitter Creek divide, head of Halls Creek.

\section{[Measured by R. C. Moore.]}

Masuk sandstone: Light-yellow massive sandstone, weathering yellowish brown; forms very prominent escarpment; in lower part grades into medium-bedded sandstone...................

"Masuk shale": Yellowish-brown to drab sandy shale; upper part contains beds and lenses of soft sandstone; forms slope beneath escarpment of sandstone above...........................

Blue Gate sandstone: Yellow to light-brown medium to massively bedded sandstone forming precipitous cliff; locally contains lignite...........

"Blue Gate shale": Bluish-drab sandy shale, very uniform in color and texture; upper part grades into soft shaly sandstone.................. 1,200

Tununk sandstone: Yellowish-brown medium to massively bedded sandstone.................. 50-75

"Tununk shale": Bluish-drab sandy shale, uniform in color and texture; includes very fossiliferous thin yellow sandstone at base................

Dakota (?) sandstone: Light-yellow soft irregularly bedded sandstone, grading upward into sandy shale; contains two thin beds of impure lignite 9 and 20 inches thick.......................

McElmo formation:

Grayish-blue, maroon, and purple banded soft sandy shale, weathering in valleys and badlands...............................
Feet. 
McElmo formation-Continued.

Grayish-white to light bluish-green conglomerate and sandstone; contains pebbles as much as 2 inches in diameter; consists in part of thick beds and lenses of coarse conglomerate and in part of coarse gritty very irregularly bedded sandstone.....................

Total thickness of McElmo formation ...

"Varicolored shales and sandstones":

Red and gray banded sandy shale grading to soft thin-bedded sandstone...............

Tan-brown massive soft cross-bedded sandstone, weathering in smooth rounded surfaces......

Reddish-brown and bluish-gray very soft shaly sandstone, weathering readily, forming valley; partly covered......................

Tan-brown massive soft cross-bedded finegrained sandstone, weathering in smooth rounded surfaces....................

Total thickness of "varicolored shales and sandstones" ...................

"Gypsiferous shales and sandstones:"

Light-red and bluish-gray shale and sandstone; gray to white sandstone in alternating beds; contains several beds of bluish to white gypsum as much as 3 feet thick; the gypsum occurs also in numerous thin veins..

Dark to light red sandy shale, containing two beds of very hard reddish and light green mottled dense siliceous massive and flaggy limestone that forms escarpments.......... .

Total thickness of "gypsiferous shales and sandstones" ....................

Navajo sandstone: White to very light creamcolored sandstone, locally stained light orangered in middle and lower parts; capped by bed of coffee-brown sandstone, 10 feet, and light tan, highly cross-bedded sandstone, 8 feet. Very massive, highly cross-bedded on large scale; the cross-beds are etched in relief by weathering; crops out in high, prominent "reef" whose surface is marked by numerous conical tepees, mosques, and rounded domes................

Todilto (?) formation: Dark-red to maroon crossbedded sandstone, medium to coarse grained, thin to medium bedded; some beds hard, others soft; bedding very irregular; locally contains soft maroon sandy shale; thickness in part estimated.

Wingate sandstone: Red very massive hard finegrained sandstone, of uniform color and texture, cross-bedded but bedding not prominent, much jointed; crops out as single ledge making a vertical cliff or palisade.......................

\section{Chinle formation:}

Light-bluish hard calcareous shale, mottled with lavender; upper part stained purple; weathers in rough angular blocks; forms slope.
Feet. Chinle formation-Continued.

Massive light greenish-blue limestone conglomerate, composed of pebbles of limestone, quartz, jasper, and sand in a lime matrix.............................

Alternating beds of light bluish-green limestone and shale, mottled with lavender; the shale is hard and calcareous, forms slopes, and grades without demarcation into limestones that are nodular, hard, and massive and form projecting ledges............... 14

Sandy shale and sandstone, yellowish brown, yellow, dark brown, blue, purple, and ashgray, dark tones predominating; sandstone in part soft and massive, in part hard, dense, cross-bedded, and forming projecting ledges, locally conglomeratic................. 304

Total thickness of Chinle formation.... 500 Shinarump conglomerate: Hard very massive, irregularly bedded light bluish-gray to white sandstone, weathering yellowish white locally; forms prominent escarpment; at this place thickness ranges from 40 to 110 feet within a short distance, average.........................

Moenkopi formation: Thin to medium-bedded ripple-marked micaceous sandstone; weathers in slopes and projecting ledges; base not exposed... 250+

Section of Shinarump conglomerate and upper part of Moenkopi formation on west side of Circle Cliffs between Horse Creek and the Peaks.

\section{[Measured by R. C. Moore.]}

Light-gray coarse-grained very massive sandstone, forming almost unbroken verticalfaced escarpment; weathers in large angular blocks........................ 30-60

Massive cross-bedded light bluish-gray sandstone, mottled and streaked along irregular joints with purple; grades upward without demarcation into sandy limestone; weathers in single massive bed softer than overlying sandstone and therefore forming a reentrant in the cliff; upper surface uneven...........

Moenkopi formation:

Chocolate-brown very sandy shale, grading into shaly sandstone; more calcareous above.

Chocolate-brown thin-bedded ripple-marked and cross-laminated sandstone..............

Chocolate-brown very micaceous sandy shale, grading in to thin shaly sandstone...........

Chocolate-brown hard shaly to platy sandstone; forms slight projecting ledge................

Brown sandy shale, grading into thin shaly sandstone; weathers as slope..............

Chocolate-brown hard platy sandstone, forming a ledge.............................

Chocolate-brown sandy shale, grading into shaly sandstone.......................
Feet.

16


Moenkopi formation-Continued.

Chocolate-brown thin-bedded ripple-marked laminated sandstone, locally weathering massive and forming a prominent projecting ledge.

Chocolate-brown sandy micaceous shale with thin seams and beds of soft sandstone; in upper part contains thin beds of shaly sandstone.

Light greenish-gray platy fine-grained micaceous sandstone, with large asymmetrical ripple marks; produces a slight bench.......

Chocolate-brown sandy micaceous shale, containing abundant thin beds of shaly sandstone which weathers in thin chips and platy slabs; weathers in gentle rounded slope............

Brown very micaceous ripple-marked sandstone, with thin light-gray bands, platy with thin shale beds between harder layers; top layer very hard and slabby.

Chocolate-brown sandy shale, with thin yellow and brown sandstone beds that make slight benches.

Light-yellow very massive hard sandstone; forms projecting wall.

Light-yellow massive sandstone, weathering in thin plates; grades into shaly sandstone; forms bench.

Chocolate-brown sandy micaceous shale......

Light-yellow massive sandstone; locally stained red on outcrop; grades locally into shaly or thin-bedded sandstone; forms prominent bench.

Yellow very shaly sandstone, grading to sandy shale.

Yellow calcareous micaceous sandstone, massive but thinly laminated, with ripple bedding; grades to shaly sandstone.

Partial thickness of Moenkopi formation. (Top of Kaibab limestone 25 to 40 feet below.)

Feet. Section of Moenkopi formation in canyon north of The Peaks, northwest of Wagonbox Mesa, in the Circle Cliffs.

[Measured by R. C. Moore.]

5

Shinarump conglomerate: Gray medium to fine grained massive sandstone, weathering yellowish in part, locally conglomeratic; weathers in large angular blocks; outcrop forms prominent cliff... 50-150

$46 \frac{1}{2}$ Moenkopi formation:

Maroon sandy shale grading into yellow shale in upper 15 feet, with many paper-thin sandstone layers.....................

Yellow fine-grained soft sandstone; weathers rather shaly .......................

Maroon shale with thin shaly sandstone.... Buff, brown, and gray fine-grained sandstone, in layers 1 to 4 inches thick...............

Yellowish-brown sandy shale. . . ..........

Pink to maroon sandstone, thin bedded, with a few massive layers as thick as 16 inches at intervals; interbedded with very sandy shale; upper part yellow-brown...........

Fine-grained hard gray and light-pink sandstone, weathering brown and light gray; weathers in beds 2 to 12 inches thick, but in fresh exposures beds appear very massive; upper part more reddish than lower; ordinarily well exposed....................

Red sandstone, with thin sandy shale interbedded, medium to massive bedding.......

Very thin bedded platy light-brown and yellow to pink sandstone, weathering reddish brown; abundant ripple marks; grades locally into shale; forms slopes..............

Pink to red sandy shale, containing thin beds of platy sandstone; weathers in slopes......

Total thickness of Moenkopi formation. .

Kaibab limestone: Deep-yellow to buff very hard fine-grained dense dolomitic limestone, in massive beds 3 to 6 feet thick; weathers in large angular blocks; forms prominent bench; exposed thickness...............................
Feet. 

183519

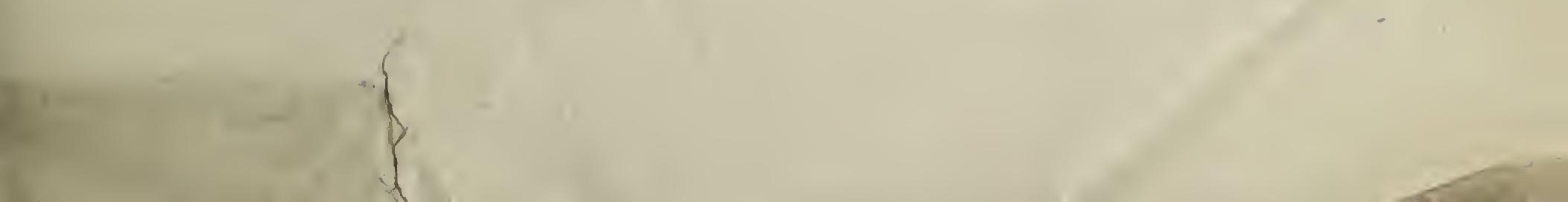



Please do not destroy or throw away this publication. If you have no further use for it, write to the Geological Survey at Washington and ask for a frank to return it

\title{
DEPARTMENT OF THE INTERIOR
}

HUBERT WORK, Secretary

UNited STATES GEOLOGICAL SURVEY

George Otis Smith, Director

Professional Paper 132-C

\section{NOTES ON THE GEOLOGY OF GREEN RIVER VALLEY BETWEEN GREEN RIVER, WYOMING, AND GREEN RIVER, UTAH}

\author{
BY \\ JOHN B. REESIDE, Jr. \\ Published November 30, 1923 \\ ( Pages 35-50)

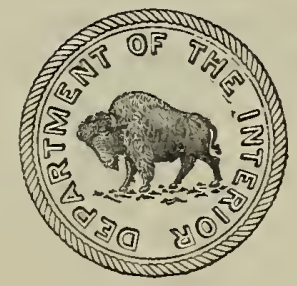 \\ WASHINGTON \\ GOVERNMENT PRINTING OFFICE \\ 1923
}


